\title{
Bacteria in sea ice and underlying brackish water at 54 26' 50" N (Baltic Sea, Kiel Bight)
}

\author{
Thomas Mock*, Klaus M. Meiners, Hanna C. Giesenhagen \\ Institut für Meereskunde an der Universität Kiel, Düsternbrooker Weg 20, D-24105 Kiel, Germany
}

\begin{abstract}
Bacterial response to the rare event of solid ice cover in the western Baltic Sea (Kiel Bight) was investigated from February to March 1996. Samples (ice cores, brine and water) were taken at a shallow, near-shore station at irregular time intervals. Bacterial abundance, biomass and production were measured in brine and the underlying water as were the concentrations of $\mathrm{NO}_{3}, \mathrm{NO}_{2}, \mathrm{NH}_{4}, \mathrm{PO}_{4}$ and $\mathrm{SiO}_{4}$. Vertical distributions of bacterial abundance, biomass, morphotypes and size classes and chlorophyll $a$ and nutrients were investigated within sea ice. A bacterial growth experiment with brine bacteria was carried out to measure bacterial carbon production via total incorporation of $\left[{ }^{3} \mathrm{H}\right]$ thymidine (TTI) and $\left[{ }^{3} \mathrm{H}\right]$ leucine (TLI). During February the abundance, biomass and production of bacteria within brine exceeded values from under-ice water, whereas the opposite was observed in March. High $\mathrm{NO}_{3}$ and $\mathrm{NH}_{4}$ concentrations in ice and under-ice water of up to $112 \mu \mathrm{M}$ and $55 \mu \mathrm{M}$, respectively, resulted in N:P ratios of 18 to 330 . Algae and bacteria were considered to benefit from that nutrient supply. For bacteria this was supported by TTI and particularly high TLI rates during the ice situation, with TLI:TTI ratios of 25 to 213. The high TLI rates were due to a large degree of unspecific labeling by leucine and characterised the bacteria during winter 1996 as extremely active. Bacterial production (based on TTI) rose in water from $0.021 \mu \mathrm{g} \mathrm{Cl}^{-1} \mathrm{~h}^{-1}$ at the beginning to $0.909 \mu \mathrm{g} \mathrm{Cl}^{-1} \mathrm{~h}^{-1}$ at the end of the investigation, and in brine from 0.122 to $0.235 \mathrm{\mu} \mathrm{C} \mathrm{C} \mathrm{l}^{-1} \mathrm{~h}^{-1}$. Abundance of bacteria in brine increased from $1.7 \times 10^{6}$ cells $\mathrm{ml}^{-1}$ initially to $2.8 \times 10^{6}$ cells $\mathrm{ml}^{-1}$ in March. The average cell volume of these bacteria was $0.2 \mu \mathrm{m}^{3}$ whereas the bacteria in water reached only $0.08 \mu \mathrm{m}^{3}$ The bacterial assemblage in the ice was dominated by large rods and in the water by small rods and cocci. Bacterivorous activity within sea ice was assumed to be reduced due to the specific vertical distribution of the different bacterial size classes. This was further supported by a good correlation between the development of the bacterial standing stock and the potential biomass, in sea ice as well as in the underlying water, calculated from generation times towards the end of the investigation. Low grazing pressure, high standing stocks of algae and sufficient substrate supply accounted for bacterial biomass within the ice and the underlying water that exceeded that from former winters by far A comparison with Arctic and Antarctic sites demonstrated that the bacterial community within the sea ice showed many similarities to those found in sea ice of polar regions.
\end{abstract}

KEY WORDS: Baltic Sea Sea ice Bacteria A Abundance Biomass Production Chlorophyll a Nutrients

\section{INTRODUCTION}

Only the northerly regions of the brackish Baltic Sea show annual ice cover, and this lasts from about 1 mo in the Gulf of Finland (Strübing 1995) to 6 mo in the Gulf of Bothnia (Norrman \& Andersson 1994). Winters with a solid ice cover occur rather rarely in the strictly temperate western Baltic Sea: over the last 30 yr about

\footnotetext{
•E-mail: tmock@ipoe.de
}

one third of all winters had appreciable ice development of $\geq 1 \mathrm{~d}$ (Strübing 1995). Solid ice coverage for more than $70 \mathrm{~d}$ has occurred only 4 times this century, the last time being during the winter of 1995/96. While the occurrence of ice-specific algae and Arctic relict fauna is well reported for the Baltic Sea (Rheinheimer 1995), only 1 study, conducted in the Gulf of Bothnia, presents data on bacteria and other organisms of the microbial food web in ice (Norrman \& Andersson 1994). No data on bacterial production in sea ice are available for the Baltic Sea. 
Sea ice is known to be inhabited by rich algal and bacterial populations in polar (Palmisano \& Garrison 1993) and subpolar regions (Normann \& Andersson 1994). The lack of annual ice cover in the western Baltic Sea makes ice likely to be an inhospitable environment for microbial growth and harmful to larger organisms. Furthermore, since ice microbial communities are known to be the result of dynamic development (Ackley \& Sullivan 1994) and bacterial abundances and activities are low during the initial stages (Grossmann \& Dieckmann 1994), ice cover in the western Baltic Sea may generally not last long enough to allow the development of ice communities. Were the ice cover to last long enough it is unknown whether or not microbes inhabiting temperate regions would have the potential to form sea ice communities as observed in high latitude areas.

At the onset of ice formation at the end

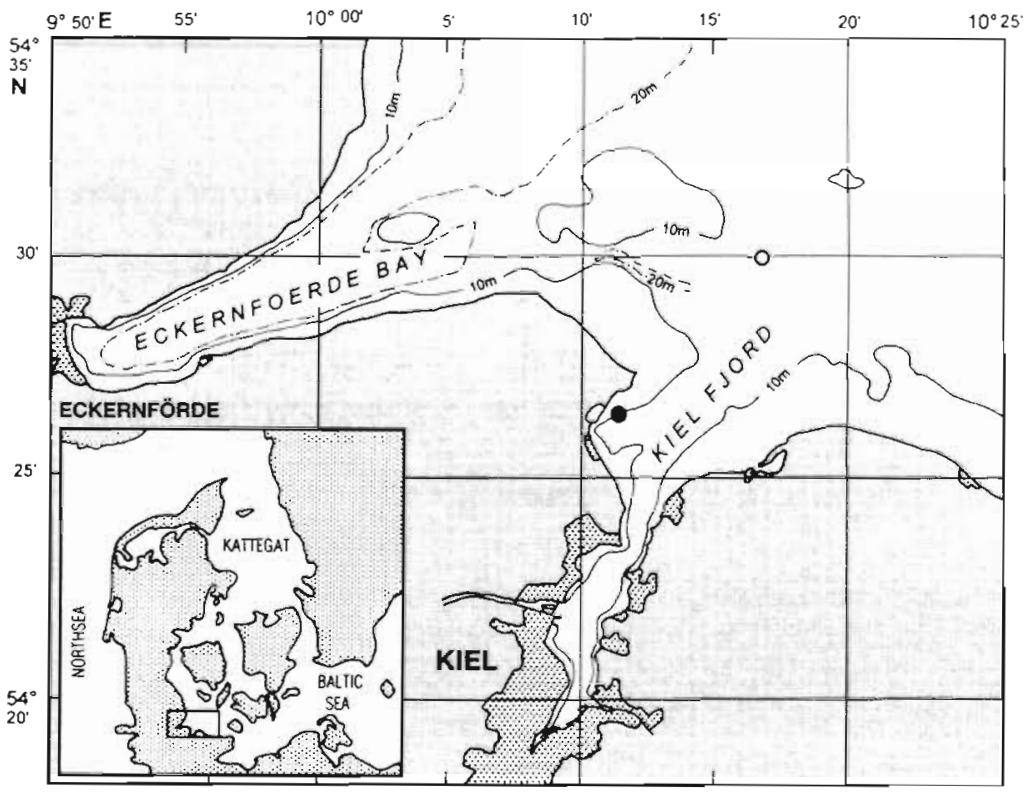

Fig. 1. Map of the Kiel Bight. (•) Sampling site 'Strander Bucht'; (0) meteorological station of January 1996 it was not anticipated that the ice would persist for more than 2 mo. Therefore, initial microbiological investigations comprised only a small set of variables which included the first measurements of bacterial production in brine and under-ice water in the Baltic Sea (Kiel Bight). Despite shortcomings during the first 2 sampling days, the final data set obtained from the brackish ice of Kiel Bight allows comparisons with the vertical distribution of ice bacterial assemblages from polar regions and from the northern part of the Baltic Sea. Bacterial production and standing crop parameters of algae and bacteria are discussed with respect to data from polar regions and to long-term data records from the Kiel Bight area.

\section{MATERIAL AND METHODS}

Site and sampling. The principal area of investigation was the 'Strander Bucht' (Fig. 1). The sampling station $\left(54^{\circ} 26^{\prime} 50^{\prime \prime} \mathrm{N}, 10^{\circ} 11^{\prime} 20^{\prime \prime}\right.$ E) was located near shore in approximately $3 \mathrm{~m}$ water depth. Sea ice was investigated from 12 Feb to 15 Mar 1996. The ice thickness at the sampling site increased from 28 to $74 \mathrm{~cm}$ over the investigation period. The fast ice sheet, often consisting of smaller and larger pancakes frozen together, was sampled using a $3^{\prime}$ SIPRE ice auger driven by a power drill.

Samples of ice biota were obtained by 2 methods: (1) The brine was sampled by drilling shallow deadend 'sack holes' into the ice. Several minutes after removing 10 to $20 \mathrm{~cm}$ cores from the ice sheet, brine

was collected by sterile syringes after rejection of the initial sample so as to exclude influences of the ice coring procedure. Brine from 5 'sack-holes' within a $1 \mathrm{~m}^{2}$ ice sheet was pooled to give 1 sample. (2) Complete ice cores were taken on 3 occasions (16 Feb, 23 Feb and 15 Mar 1996). To minimize horizontal heterogenity, ice cores were taken less than $50 \mathrm{~cm}$ apart. The ice temperature was recorded at $5 \mathrm{~cm}$ intervals immediately after coring. Thereafter, cores were cut with a stainless steel saw into $10 \mathrm{~cm}$ sections which were occasionally subdivided into $7,6,4,3$, or $2 \mathrm{~cm}$ sections. Sections were transferred into clean polyethylene boxes. Three cores were then used for salinity and chlorophyll determination (no. 1), for inorganic nutrient concentrations (no. 2) and for analysis of bacteria distribution (no. 3 ).

Samples of under-ice water were obtained by cutting a hole of approximately $0.5 \mathrm{~m}^{2}$ into the sea ice. The seawater was sampled using sterile syringes. The temperature of brine and under-ice water was measured directly during the sampling procedure. The brine and water samples were immediately subsampled for total bacterial number (TBN) and biomass (TBB) (100 ml fixed with a final concentration of $2 \%$ formaldehyde), for nutrients $(50 \mathrm{ml})$, and finally for bacterial production $(1000 \mathrm{ml})$. All samples were kept at a constant low temperature of -1 to $0^{\circ} \mathrm{C}$ and transported to the laboratory for further processing within $3 \mathrm{~h}$ after collection.

Salinity, physico-chemical parameters and pigments. For salinity, nutrient and pigment concentrations, ice core sections were melted at $4^{\circ} \mathrm{C}$ in the dark. Salin- 
ity was measured by a WTW LF 191 conductometer. Nutrients were determined using a Kiel-Autoanalyzer and standard seawater procedures (Grasshoff et al. 1983). For the determination of algal pigments [chlorophyll a (chl a) and phaeopigments from sea ice only] thawed core sections were filtered onto Whatman GF/F filters and analysed fluorometrically with a Turner Designs Model 10-AU digital fluorometer according to Arar \& Collins (1992). Particulate ice algae carbon (PIAC) was calculated using a carbon:chl a ratio of 50:1 (Andersson \& Rudehäll 1993). Salinity of brine and under-ice water was measured immediately after the sampling procedure and nutrient concentrations were determined within $3 \mathrm{~h}$ of collection using the same methods as for the ice samples. Brine content was calculated following the equations given by Frankenstein \& Garner (1967) and Leppäranta \& Manninen (1988). Nutrient concentrations were normalized to the salinity of under-ice water for each sampling day (Gleitz et al. 1995)

Bacterial cell number, biomass and morphotypes. The ice core segments of the bacteriological cores were melted overnight in $2 \mathrm{l}$ of $0.2 \mu \mathrm{m}$ pre-filtered seawater at $3^{\circ} \mathrm{C}$ to avoid osmotic stress to the ice bacteria during the melting procedure (Garrison \& Buck 1986, Spindler \& Dieckmann 1986). Sub-samples of $100 \mathrm{ml}$ from each segment of the cores were fixed with borax-buffered formalin $(2 \%$ final concentration formaldehydel. Subsequently, all fixed bacteria samples (water, brine and ice) were filtered onto black $0.2 \mu \mathrm{m}$ polycarbonate filters (Millipore, Poretics) and stained for 5 min with $0.03 \%$ Acridine Orange solution in triplicate. Preparates were stored frozen $\left(-18^{\circ} \mathrm{C}\right)$ and counted within $3 \mathrm{wk}$ (Turley \& Hughes 1992). Microscopic analyses were carried out with either a Zeiss Axioplan or Axioskop epifluorescence microscope under blue-light excitation (450 to $490 \mathrm{~nm}$ ). Total bacterial number was calculated from at least 400 cells recorded in a minimum of 20 fields of a New Porton G12 counting grid (Graticules Ltd, UK). Estimates of bacterial biovolume were based on measurements of 100 individual cells on every filter. Biovolume was converted into bacterial carbon using the formula $\mathrm{CC}=88.6 \times \mathrm{vol}^{0.59} \times 1.042$ (Simon \& Azam 1989), where CC and vol are the average carbon content per cell and the average cell volume, respectively. Bacterial cell volumes were grouped into size classes which corresponded to volumes of: $<0.025$, $0.025-0.135,>0.135-0.47$ and $>0.47 \mu \mathrm{m}^{3}$. Bacteria were also grouped according to morphotypes such as: cocci, vibrios, rods and 'others'. The group 'others' contained bacteria of e.g. spirillum-, spirochaete-, or flexibacter-like shape. Scanning electron micrographs of bacteria were carried out using a Zeiss DSM 940 microscope.
Bacterial processes. Incorporation of $\left[{ }^{3} \mathrm{H}\right]$ leucine and $\left[{ }^{3} \mathrm{H}\right]$ thymidine: The determination of bacterial production by incorporation rates of leucine and thymidine roughly followed the protocols described by Simon \& Azam (1989) and Fuhrman \& Azam (1982), respectively. Triplicate 5 to $10 \mathrm{ml}$ samples (water and brine) and 1 formalin prefixed blank ( $1 \%$ final concentration) were incubated at in situ temperature of -1 to $0^{\circ} \mathrm{C}$ for 60 or $120 \mathrm{~min}$ : one set was amended with 74 to $111 \mathrm{kBq}$ L- $\left[4,5-{ }^{3} \mathrm{H}\right]$ leucine (specific activity 2.3 to $3.3 \mathrm{TBq} \mathrm{mmol}^{-1}$, Amersham) and diluted with unlabeled leucine to a final concentration of 100 to $110 \mathrm{nM}$, and a second set received $10 \mathrm{nM}$ [methyl- ${ }^{3} \mathrm{H}$ ]thymidine (specific activity $2.26 \mathrm{TBq}^{-1} \mathrm{mmol}^{-1}$. Amersham).

To obtain the cold trichloroacetic acid (TCA) insoluble macromolecular fraction, incubation was stopped by addition of formalin (final concentration $1 \%$ formaldehyde). Samples were filtered onto $0.2 \mu \mathrm{m}$ polycarbonate filters (Costar, Poretics) and rinsed 10 times

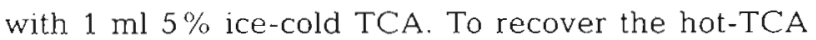
insoluble fraction (additional sample sets only on 15 Mar) incubation was stopped with TCA ( $5 \%$ final concentration) and immediately extracted for $20 \mathrm{~min}$ in a hot water bath $\left(80^{\circ} \mathrm{C}\right)$. After cooling in an ice bath, the material was collected on $0.2 \mu \mathrm{m}$ polycarbonate filters and rinsed 5 times with $1 \mathrm{ml} 5 \%$ ice-cold TCA. All filters were transferred into Lumagel scintillation cocktail (Baker) and radioassayed in a Packard TriCarb liquid scintillation counter. Quench correction was performed by automatic external standardization.

Bacterial carbon production and growth rates: To convert incorporation rates to rates of macromolecular synthesis and, in turn, to biomass production, empirical conversion factors were used from an experiment with natural bacterial assemblages taken directly from the brine on 16 Feb 1996. In this time-course experiment, the increase of bacterial cell concentration was followed by epifluorescence microscopy parallel with measurements of thymidine and leucine incorporation. $400 \mathrm{ml}$ of brine were filtered through $1 \mu \mathrm{m}$ polycarbonate filters to eliminate grazers. The inoculum was diluted 10 -fold with brine filtered through $0.16 \mu \mathrm{m}$ by tangential filtration (Ultrasette, Filtron). Growth of bacteria was followed at $0^{\circ} \mathrm{C}$ maintained by an ice bath in an insulated box for $171 \mathrm{~h}$. Conversion factors were calculated from the slope of cell numbers at a time point vs the incorporation rates integrated to that time point (integrative method; cf. Kirchman \& Ducklow 1993). Carbon production of field samples was then calculated from incorporation rates multiplied by the obtained conversion factors and the average carbon content per cell of the respective sample. Specific bacterial growth rates $(\mu)$ were estimated from the production/biomass ratio and corresponding generation times (G) were calculated by $G=\ln 2 / \mu$. 


\section{RESULTS}

Two steady easterly wind fields led to a long-lasting cold period during the winter of 1996 (Fig. 2a). After $10 \mathrm{~d}$ of air temperatures below $0^{\circ} \mathrm{C}$, the ice formation process in the brackish water started (about $27 \mathrm{Jan}$ ) (Fig. 2b), and the first sample of a closed solid ice sheet was taken 16 d later. North and west wind events between these wind fields were responsible for short periods of 'milder weather'. Air temperatures above $0^{\circ} \mathrm{C}$ led to superficial ice melting processes but not to a general warming of seawater. The changes in wind direction were followed by ice drifting and later on by repacking of single ice floes, altering the ice situation from solid to pack ice. This near-shore land-fast ice was broken up by strong westerly winds during the third week of March and drifted offshore.

The weather conditions directly influenced temporal and spatial development of the physical and chemical variables of sea ice during the study. In situ temperature in the brine increased during the investigation period (Fig. 3a) whereas salinity gradually decreased over time (Fig. 3b). Salinity and temperature in the under-ice water did not show any trend. Salinity of the ice cores also exhibited no clear temporal development (Fig. 4) but the temperature of the sea ice increased slightly over time (Fig. 5). This trend was reflected by an increase in the relative brine content of the mid and lower horizons of the ice cores (Fig. 4). Here, brine contents of well above $40 \%$ towards the end of the inves-
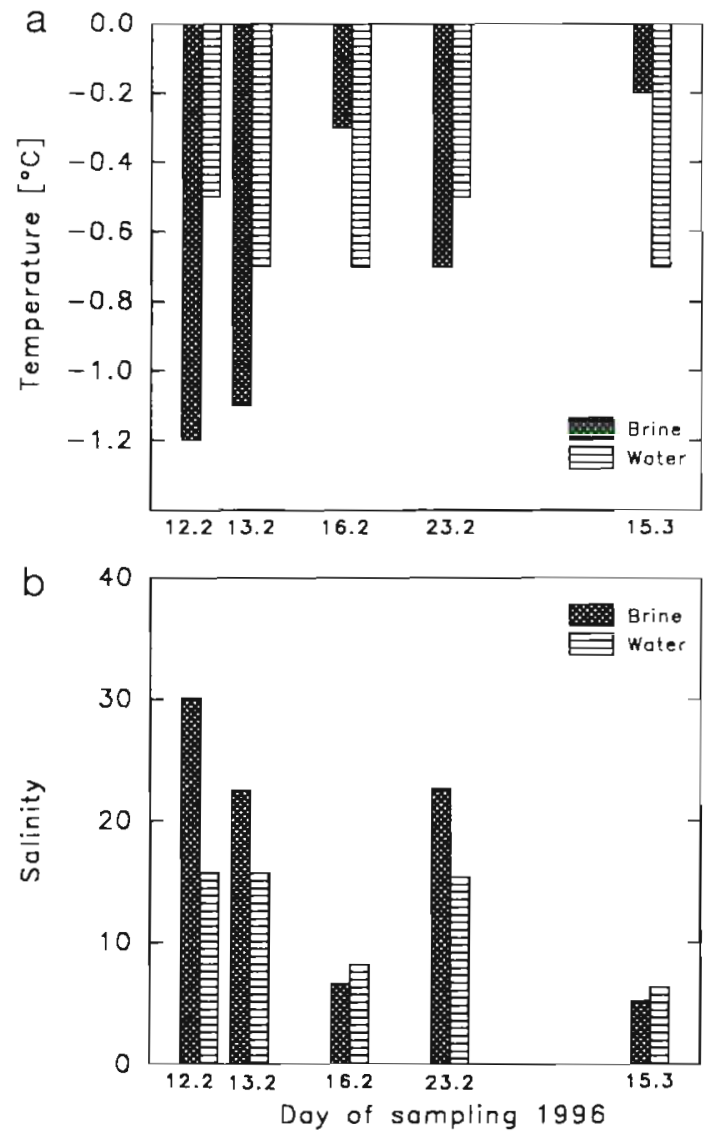

Fig. 3. Brine and water (a) temperature and (b) salinity. (Dates are day.month)
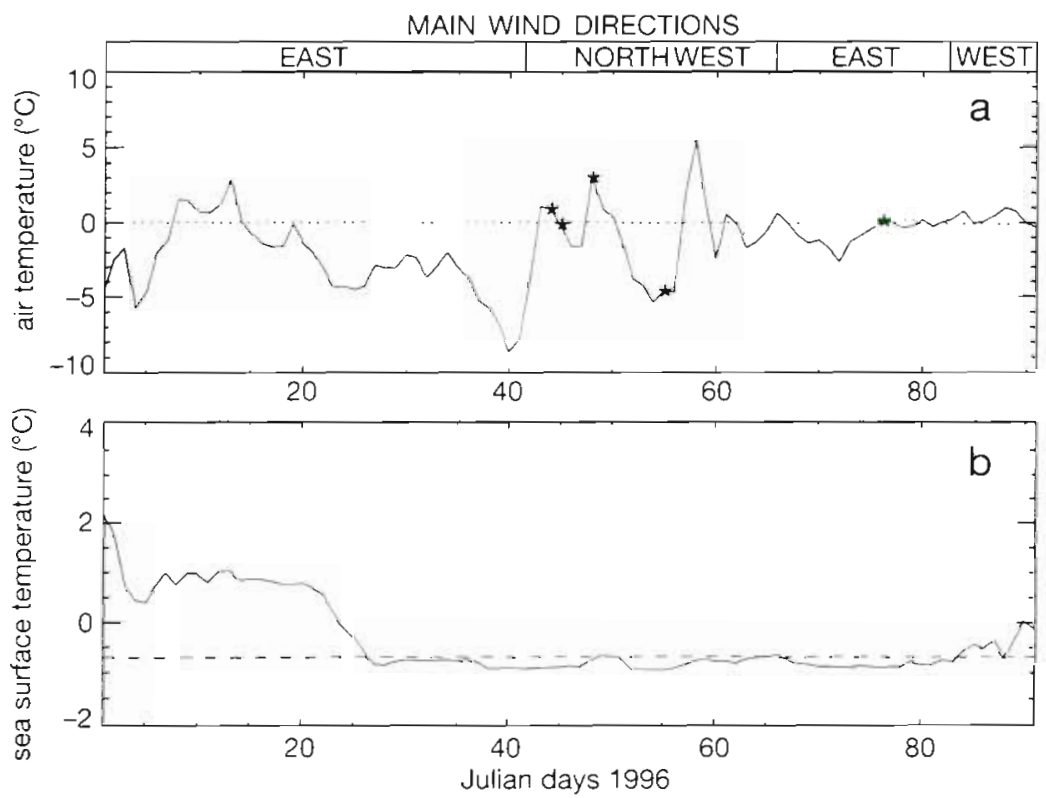

Fig. 2. Time course of (a) air temperature with main wind directions and stars indicating sampling dates (from left to right: Feb 12, 13, 16, 23 and Mar 15), and (b) surface water temperatures. Dashed line in (b) indicates freezing point of brackish water with a salinity of 15 tigation characterised the ice as extremely porous and wet and provided a large inner surface as a possible habitat for microorganisms.

The change of inorganic nutrients over time (Fig 6) indicated a similar development in sea ice, brine and underlying water with highest nutrient concentrations always occurring in the latter. Nitrite and silicate increased in ice and water from 16 Feb to the end of the study, whereas phosphate only increased in water. Silicate rapidly exceeded the initially low values by a factor of more than 20 with peak values of $45 \mu \mathrm{M}$ in water on 15 Mar. Nitrate was the dominant inorganic nitrogen compound and ammonia was also present in high concentrations. N:P ratios of 18 to 330 indicated a possible strong phosphate deficiency in ice, brine and water. Table 1 contains ice nutrient data normalized to the salinity of the under- 
16 Feb 1996

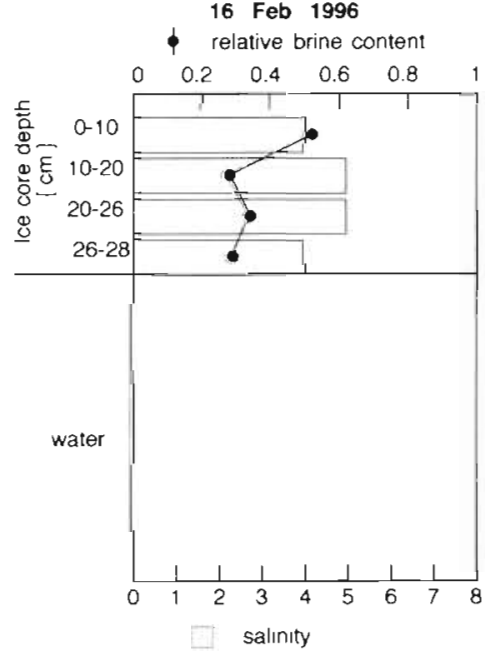

16 Feb 1996

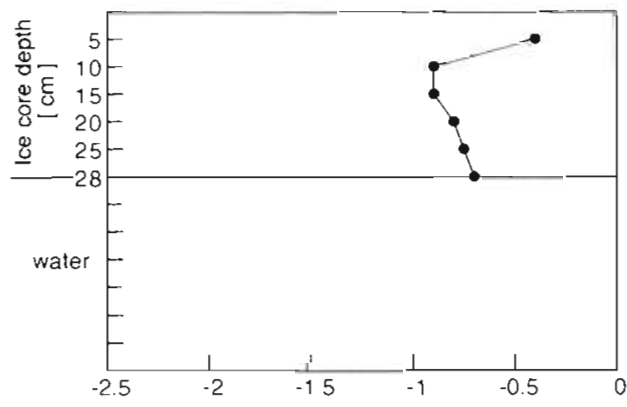

23 Feb 1996
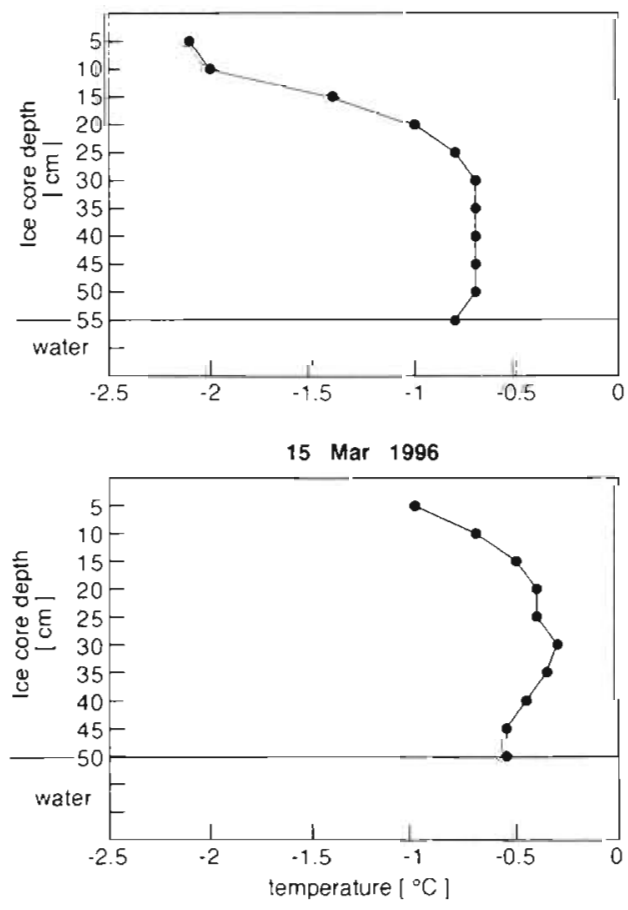

Fig. 5. Vertical temperature profiles in sea ice
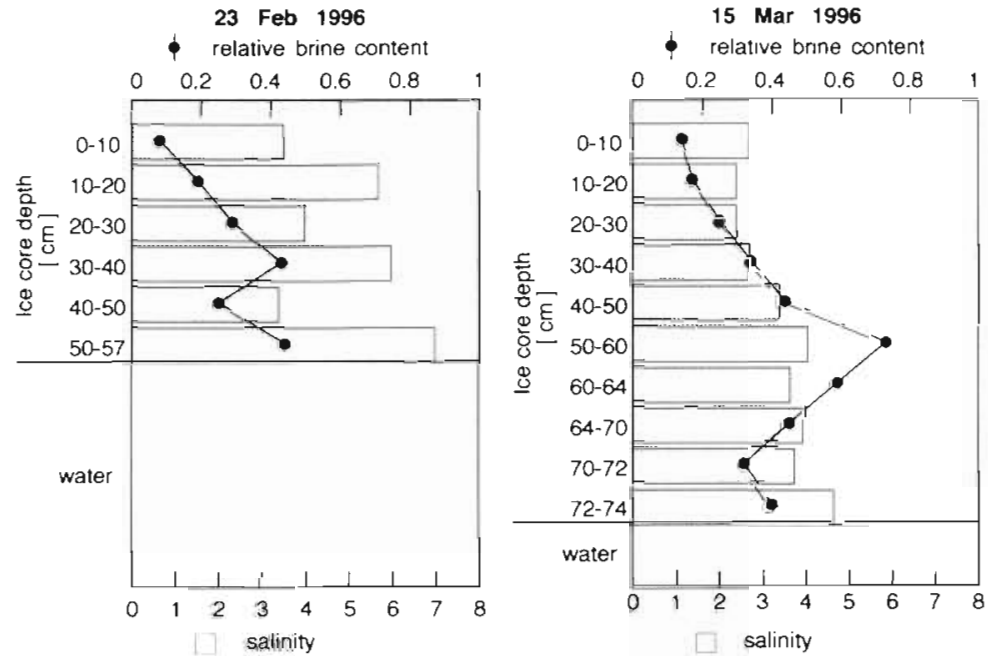

lying water on the respective and the first sampling day to exclude possible biological effects from the data set.

Measurements of the vertical distribution of chl a revealed an increasing concentration from top to bottom. However, an inverse vertical distribution was observed on 23 Feb. Phaeopigment:chlorophyll ratios did not exceed 0.4 (Fig. 7).

TBN and TBB in brine showed a slow decline until 16 Feb followed by a pronounced increase, reaching maximum values of $2.8 \times 10^{6}$ cells $\mathrm{ml}^{-1}$ and $51.3 \mu \mathrm{g} \mathrm{Cl}^{-1}$ on 15 Mar (Fig. 8). TBN and TBB in underlying water increased steadily during the study and exceeded the brine values on 15 Mar. While there were no similarities in the vertical distributions of TBN, TBB and chl a on 16 Feb, a similar vertical distribution of these variables was detected on 23 Feb and 15 Mar (Figs. 7 \& 9). The average biovolume of sea ice bacteria was $0.2 \mu^{3}$ whereas the bacteria in water reached an average biovolume of only $0.08 \mu^{3}$. The most frequent size class in sea ice was 0.025 to $0.135 \mu^{3}$ and reached maximum values in the bottom sections whereas bacteria larger than $0.135 \mu^{3}$ and smaller than $0.025 \mu^{3}$ were more abundant in the upper sections of each ice core (Fig. 10). This pattern evolved over time and was most pronounced on 15 Mar. The distribution of bacterial size classes of the underlying water was different to that of sea ice. The water was dominated by 2 bacterial size classes: $<0.025 \mu \mathrm{m}^{3}$ and $0.025-0.135 \mu^{3}$ while larger cells were very scarce.

Size classes were often represented by distinct morphological types. Cocci contributed mostly to smaller size classes while vibrios, rods and 'others' were dispersed evenly over the entire size spectrum. The 4 groups of morphotypes showed a relatively homogenous vertical distribution (Fig. 11). Cocci and rods were the most frequent morphotypes in the ice as well 
16 Feb 1996
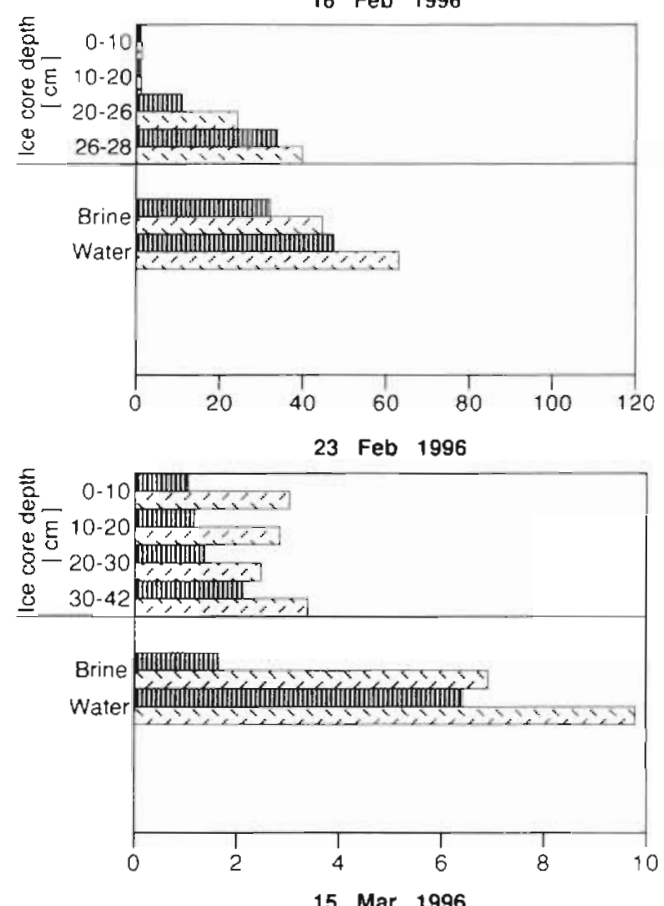

15 Mar 1996

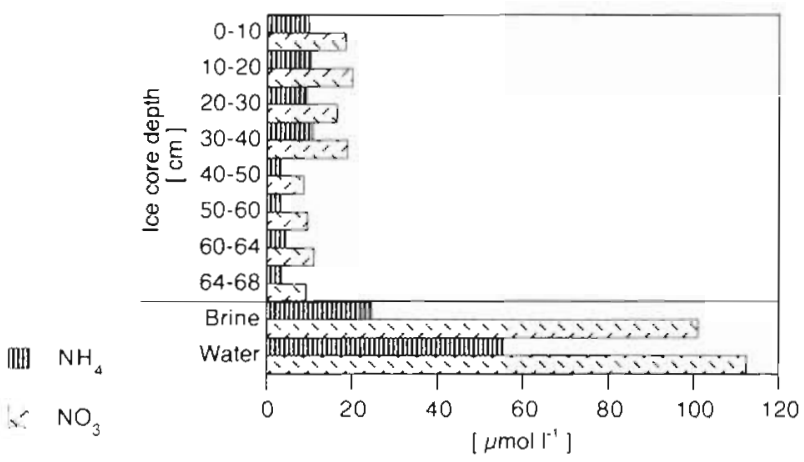

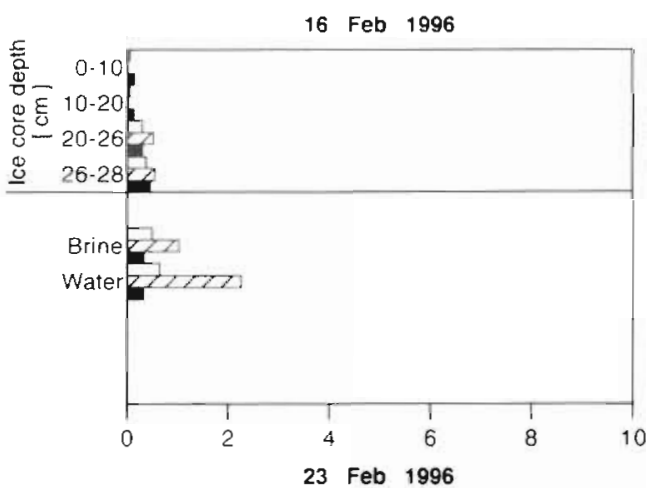

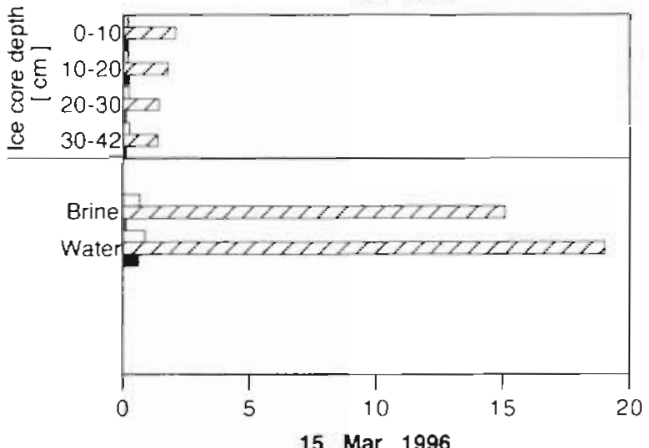

15 Mar 1996

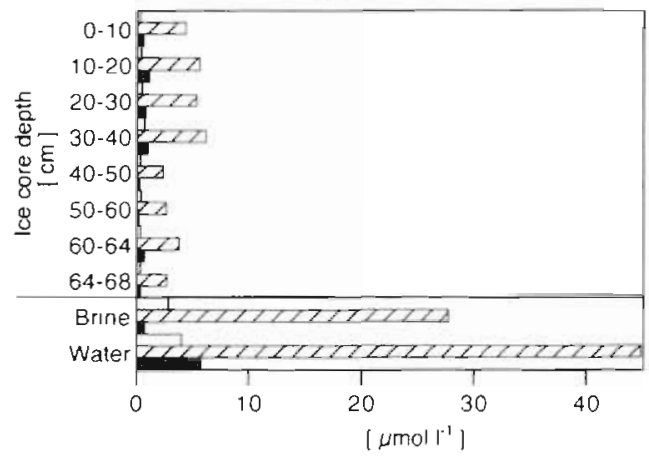

$\mathrm{NO}_{2}$

$7 \mathrm{SiO}_{4}$

$\mathrm{PO}_{4}$

Fig. 6. Vertical nutrient profiles in sea ice. Nutrient concentrations in under-ice water and brine are shown beneath the ice values
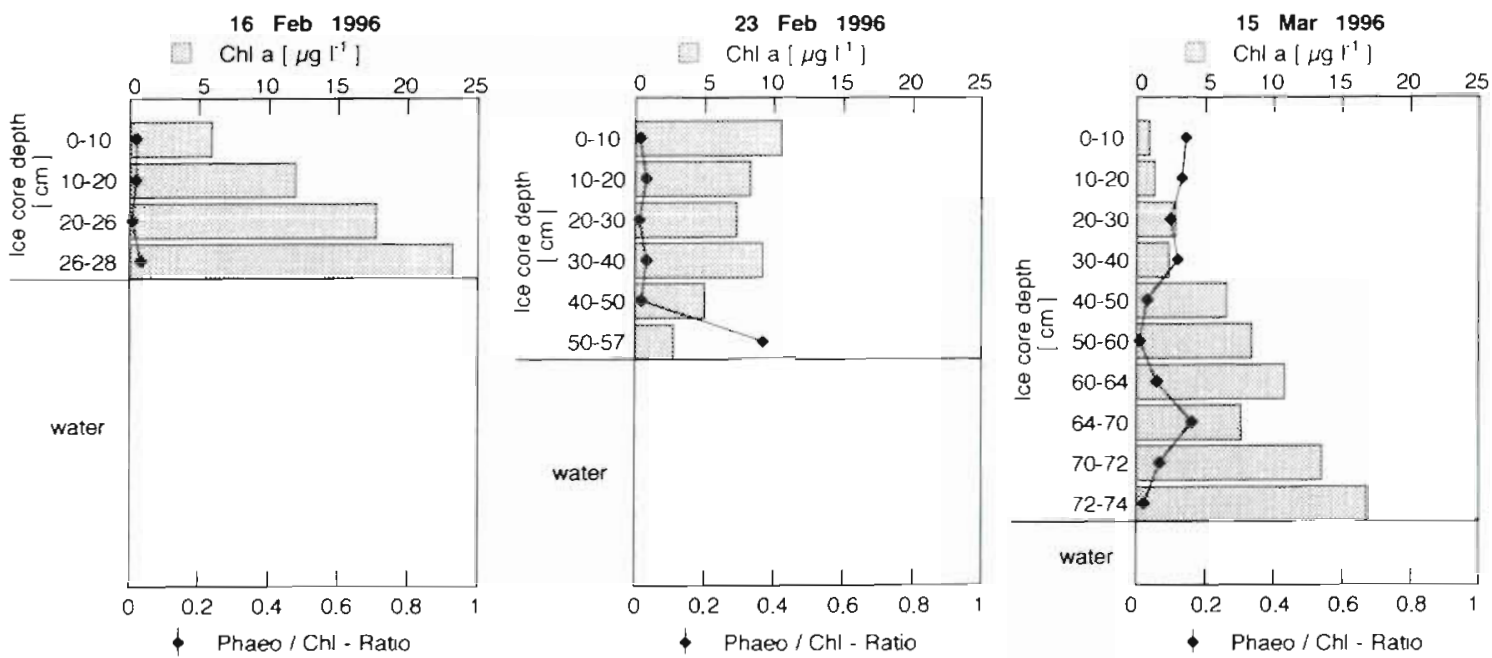

Fig. 7. Chlorophyll a distribution and phaeophytin/chlorophyll ratios within sea ice 
Table 1. Nutrient concentrations $\left(\mu \mathrm{mol} \mathrm{l} \mathrm{l}^{-1}\right)$ within brine normalized to the salinity of the underlying water of the sampling date (") and normalized to the salınity of under-ice water on 16 Feb $(\cdots)$

\begin{tabular}{|c|c|c|c|}
\hline Nutrient & 16 Feb 1996 & 23 Feb 1996 & 15 Mar 1996 \\
\hline $\begin{array}{l}\mathrm{NH}_{4} \cdot \\
\mathrm{NH}_{4} \cdot \cdot\end{array}$ & $\begin{array}{l}40.0 \\
40.0\end{array}$ & $\begin{array}{l}1.1 \\
4.5\end{array}$ & $\begin{array}{l}29.7 \\
38.6\end{array}$ \\
\hline $\begin{array}{l}\mathrm{NO}_{3}{ }^{\circ} \\
\mathrm{NO}_{3}\end{array}$ & $\begin{array}{l}55.7 \\
55.7\end{array}$ & $\begin{array}{r}4.7 \\
19.0\end{array}$ & $\begin{array}{l}122.5 \\
159.4\end{array}$ \\
\hline $\begin{array}{l}\mathrm{NO}_{2}{ }^{\circ} \\
\mathrm{NO}_{2} \cdot\end{array}$ & $\begin{array}{l}0.6 \\
0.6\end{array}$ & $\begin{array}{l}0.5 \\
1.8\end{array}$ & $\begin{array}{l}3.4 \\
4.4\end{array}$ \\
\hline $\begin{array}{l}\mathrm{SiO}_{4}{ }^{\circ} \\
\mathrm{SiO}_{4}\end{array}$ & $\begin{array}{l}1.3 \\
1.3\end{array}$ & $\begin{array}{l}10.3 \\
41.7\end{array}$ & $\begin{array}{l}33.7 \\
43.8\end{array}$ \\
\hline $\mathrm{PO}_{4}{ }^{\circ}$ & 0.4 & 0.1 & 0.9 \\
\hline $\mathrm{PO}_{4}^{4} \cdots$ & 0.4 & 0.3 & 1.2 \\
\hline
\end{tabular}

as in the underlying water but rods clearly dominated in the ice whereas rods together with cocci dominated in the underlying water. The group 'others' as detected by epifluorescence microcopy became depleted over time.
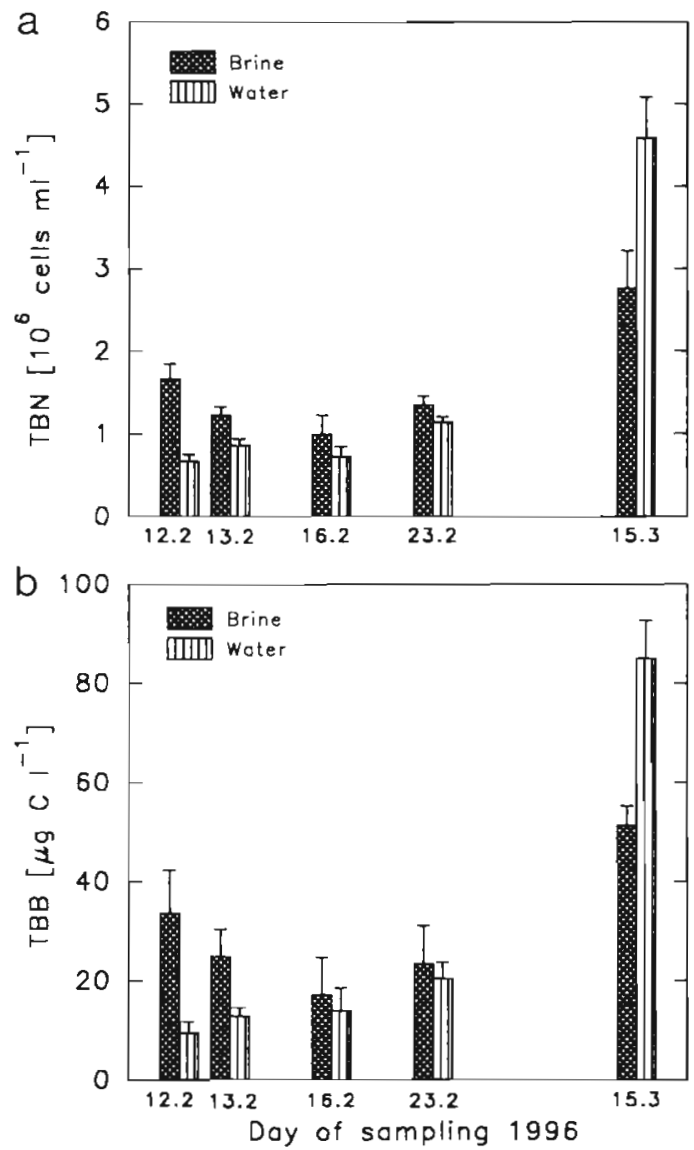

Fig. 8. Time course of (a) total bacterial number (TBN), and (b) total bacterial biomass (TBB) in brine and under-ice water. Error bars denote standard deviations
A striking deviation from the overall pattern was observed within the top ice core section on 23 Feb when $64 \%$ of vibrios and $1 \%$ of rods $(11 \%$ of total $)$ were hyphenating bacteria. Some flagellated bacteria and bacteria with smaller appendages or slime sheaths were also observed in ice on 15 Mar with the scanning electron microscope (Fig. 12).

Rates of total $\left[{ }^{3} \mathrm{H}\right.$ )thymidine incorporation (TTI) into the cold TCA-insoluble fraction between 12 and 23 Feb exhibited higher values in brine than in the water (Fig. 13a). On 15 Mar, the TTI in water increased 15 fold while that in brine only 2 -fold. The TTI in underlying water thus exceeded that of brine. Rates of $\left[{ }^{3} \mathrm{H}\right]$ leucine incorporation (TLl) into the cold TCAinsoluble material (Fig. 13b) were also higher in brine than in water except on 15 Mar and corresponded to that of TTI. However, TLI rates were unexpectedly high and the TLI:TTI ratios reached magnitudes between 25 and 213. The growth experiment (Fig. 14) conducted with ice bacteria resulted in TLI:TTI ratios of 25 to 350 and conversion factors (CF) of $1.23 \times$ $10^{6}$ cells pmol ${ }^{-1}$ for $\left[{ }^{3} \mathrm{H}\right]$ thymidine and $0.4 \mathrm{ng} \mathrm{C} \mathrm{pmol}^{-1}$ $\left(0.04 \times 10^{6}\right.$ cells $\left.\mathrm{pmol}^{-1}\right)$ for $\left.l^{3} \mathrm{H}\right]$ leucine. The high TLI:TTI ratios in this conversion factor experiment were not detected in an open water experiment about 1 wk later using the same methodology (data not shown). The high TLI:TTI ratios eventually made the use of the hot-TCA extraction procedure inevitable. Hydrolyzation of non-protein macromolecules was carried out on 15 Mar and unspecific labeling was checked. The amount of $\left[{ }^{3} \mathrm{H}\right]$ leucine incorporated into hot-TCA insoluble material in water was 9-fold lower than the $\left[{ }^{3} \mathrm{H}\right]$ leucine recovered in cold-TCA insoluble material and that in brine was about half of the $\left[{ }^{3} \mathrm{H}\right]$ leucine recovered in the cold-extracted fraction (Fig. 13b). The determined CF for $\left[{ }^{3} \mathrm{H}\right]$ thymidine incorporation led to bacterial production values in water of $0.021 \mu \mathrm{C} \mathrm{Cl}^{-1} \mathrm{~h}^{-1}$ at the beginning and $0.909 \mu \mathrm{g} \mathrm{C} \mathrm{l^{-1 }}$ $\mathrm{h}^{-1}$ at the end of the investigation. and in brine of 0.122 and $0.235 \mathrm{\mu g} \mathrm{C} \mathrm{l}^{-1} \mathrm{~h}^{-1}$, respectively.

Although bacterial carbon production (based on TTI) and biomass varied remarkably during the investigation period, generation times between 5.6 and $8 \mathrm{~d}$ within the ice were stable. Only on 16 Feb were generation times of $20 \mathrm{~d}$ observed. In the under-ice water generation times were always twice as high as in the ice except on 15 Mar when they decreased sharply to $2.7 \mathrm{~d}$.

\section{DISCUSSION}

The western Baltic Sea was covered for 2 mo with a highly variable ice sheet with respect to changes in the extension of the floe sizes and of the ice sheet itself. 
TBN

16 Feb 1996

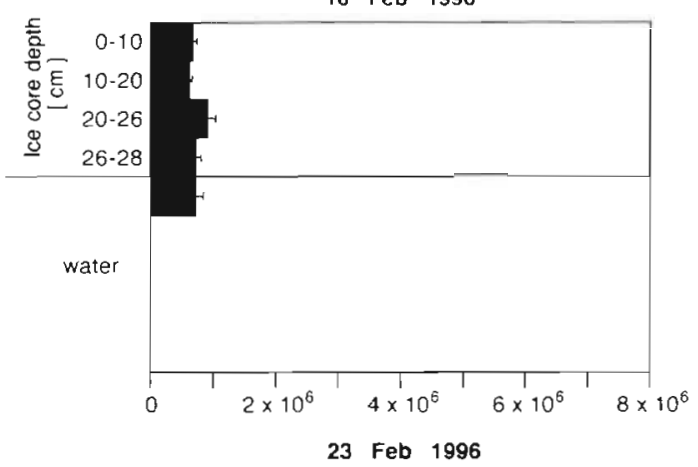

TBB

16 Feb 1996
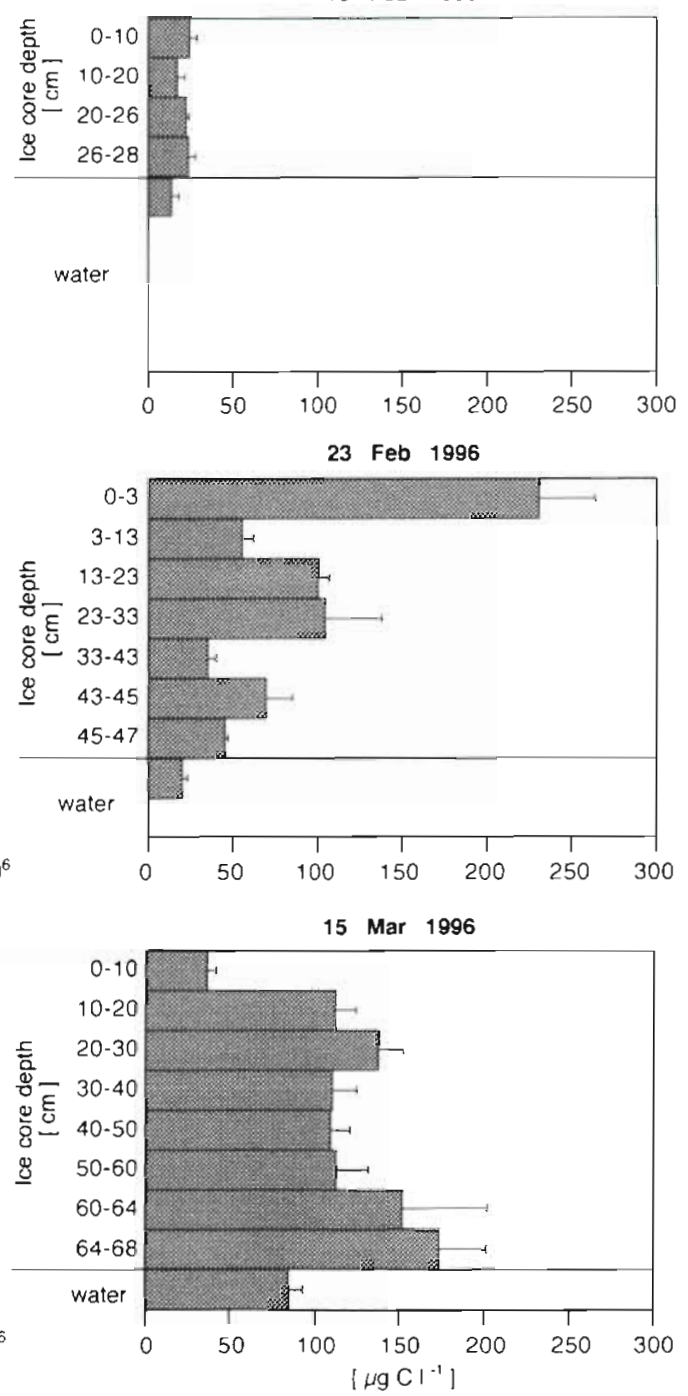

Fig. 9. Vertical profiles of total bacterial number (TBN) and total bacteria] biomass (TBB) in sea ice. Error bars denote standard deviations
The distinct changes in the under-ice water salinity point towards massive transport of water of completely different origin, a phenomenon which is likewise inconsistent with hydrographical processes in polar areas.

One characteristic feature of the investigated ice cover was the low salinity of the brine. The colder the ice, the more of the salt solution retained within freezes and concentrates (Cox \& Weeks 1983). On 16 Feb, air temperatures increased to about $3^{\circ} \mathrm{C}$ and small freshwater pools formed on the ice. Water drained through the ice, consequently reducing the salinity of the brine (6.6 psu). We assume that the always small difference in salinity between underlying water and brine was not sufficient to be a physiologically suppressive factor as is the highly saline water in brine channels in polar sea ice (Legendre et al. 1992).
Inorganic nutrients of the underlying water showed high concentrations compared to the long-term average (March) for water of the investigated area relative to time of the year (Table 2; Hansen 1993). Compared to a study from the Gulf of Bothnia (Norman \& Andersson 1994), an area of similar nutrient concentrations within the water column during wintertime (HELCOM 1997), we detected lower concentrations of ammonia and nitrate but similar concentrations of phosphate in melted ice cores (Fig. 6). Atmospheric precipitation is discussed by Norman \& Andersson (1994) and considered to be a major factor influencing the nitrate pool. During our investigation precipitation was low. We did not observe high nitrate concentrations in rain water and snow collected from the sea ice surface on 23 Feb (data not shown). Furthermore, we did not note any accumulation of nitrate on 16 Feb in the top segments of melted ice cores after rain, but 

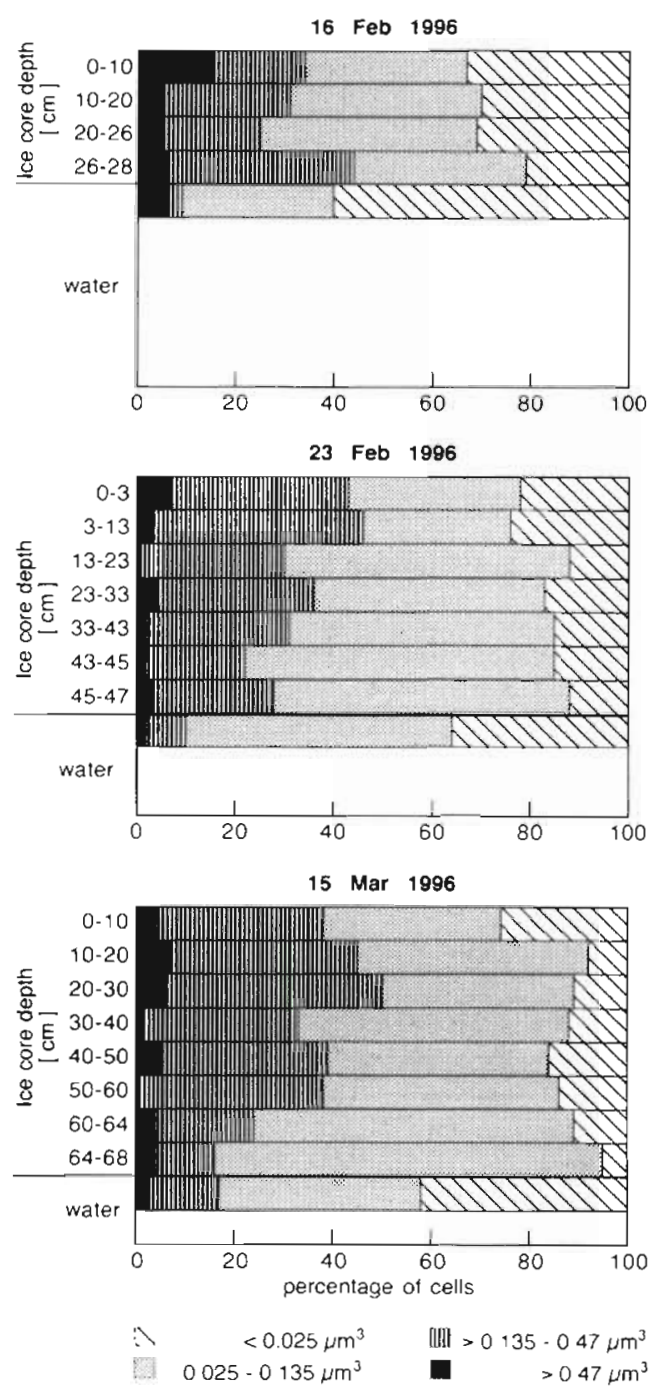

Fig. 10. Vertical distribution of bacterial size classes in sea ice and size classes for the under-ice bacterial assemblage there were extremely high nitrate concentrations for this area in the brine and under-ice water (Fig. 6). Contrary to the precipitation hypothesis, we assume 2 other factors to have chiefly caused the high nutrient contentrations: (1) Due to the shallow depth of the water and a cold unstratified water column, physical, chemical and biological properties of the underlying sediment strongly influenced the measured nutrient concentrations in our study. High values could be maintained by equilibrium reactions between the water column and the sediment (Balzer et al. 1987, Smetacek et al. 1987). (2) The up to 10-fold higher nitrate concentrations in the under-ice water compared to normal winter water values could be provided by input from eutrophic rivers, e.g. the Schwentine river which runs into the inner Kiel Fjord. Due to its low density, freshwater would travel beneath the ice and would hardly be affected by dilution. This is supported by the coincidence of very low salinities and high nutrient concentrations (ammonia and nitrate) on 16 Feb and 15 Mar. If either of these 2 factors is valid, then the nutrient concentrations in the ice were primarily a result of their concentration in the underlying water, with decreasing concentrations from bottom to top, further modified by physical and biological processes in the ice, and not substantially influenced by the atmosphere.

Due to the wide range of nutrient concentrations measured in studies from Arctic (Maestrini et al. 1986, Cota et al. 1987. Smith et al. 1990, Hudier \& Ingram 1994) and Antarctic sea ice (Dieckmann et al. 1991, Gleitz et al. 1995) a comparison is difficult because the studies were carried out at different seasons and data were usually not normalized to accord with salinities of the surrounding seawater. Generally high nutrient concentrations for water were observed in Antarctica

Table 2. Comparison among nutrient concentrations $\left(\mu \mathrm{mol} 1^{-1}\right)$ of polar regions and of the Baltic Sea in brine, ice and under-ice water; values are ranges or means

\begin{tabular}{|c|c|c|c|c|c|c|c|}
\hline & Phosphate & Ammonia & Nitrate & Silicate & Area & Season & Source \\
\hline Brine & $\begin{array}{l}2.7 \\
0.27-4.03 \\
3.1 \\
0.1-0.8\end{array}$ & $\begin{array}{c}0.63-21.89 \\
4.7 \\
1-09-33.3\end{array}$ & $\begin{array}{c}34.5 \\
1-59.3 \\
4.7^{\mathrm{a}} \\
5.31-101.5\end{array}$ & $\begin{array}{c}151.2 \\
11.8-146.2 \\
4 \\
1.01-30.23\end{array}$ & $\begin{array}{l}\text { Antarctica } \\
\text { Antarctica } \\
\text { Arctic } \\
\text { Kiel Fjord }\end{array}$ & $\begin{array}{l}\text { Winter } \\
\text { Fall/winter } \\
\text { Spring } \\
\text { Winter }\end{array}$ & $\begin{array}{l}\text { Dieckmann et al. (1991) } \\
\text { Gleitz et al. (1995) } \\
\text { Maestrini et al. (1986) } \\
\text { This study }\end{array}$ \\
\hline Ice & $\begin{array}{c}0.2 \\
0.5-3 \\
0-1.6 \\
0.11-1.15\end{array}$ & $\begin{array}{c}10-150 \\
1.04-34.2\end{array}$ & $\begin{array}{c}5.6 \\
3-6 \\
5-130 \\
1.4-40.1\end{array}$ & $\begin{array}{c}6.9 \\
5-12 \\
0-6.2\end{array}$ & $\begin{array}{l}\text { Antarctica } \\
\text { Arctic } \\
\text { Gulf of Bothnia } \\
\text { Kiel Fjord }\end{array}$ & $\begin{array}{l}\text { Winter } \\
\text { Spring } \\
\text { Winter } \\
\text { Winter }\end{array}$ & $\begin{array}{l}\text { Dieckmann et al. (1991) } \\
\text { Cota et al. (1987) } \\
\text { Norrmann \& Anderssen (1994) } \\
\text { This study }\end{array}$ \\
\hline $\begin{array}{l}\text { Under-ice } \\
\text { water }\end{array}$ & $\begin{array}{c}0.3 \\
0.85-1.15 \\
1.95 \\
0.33-5.79\end{array}$ & $\begin{array}{c}1.4 \\
1.45 \\
6.37-56.1\end{array}$ & $\begin{array}{c}2 \\
3.9-5.2 \\
29 \\
9.67-112.7\end{array}$ & $\begin{array}{c}9.9 \\
5.5-12 \\
63 \\
2.26-45.09\end{array}$ & $\begin{array}{l}\text { Arctic } \\
\text { Arctic } \\
\text { Antarctica } \\
\text { Kiel Fjord }\end{array}$ & $\begin{array}{l}\text { Spring } \\
\text { Spring } \\
\text { Fall/winter } \\
\text { Winter }\end{array}$ & $\begin{array}{l}\text { Maestrini et al. (1986) } \\
\text { Hudier \& Ingram (1994) } \\
\text { Gleitz et al. (1995) } \\
\text { This study }\end{array}$ \\
\hline Winter water & 0.88 & & 11 & 15.25 & Kiel Bight & 1 March & Hansen (1993) \\
\hline
\end{tabular}



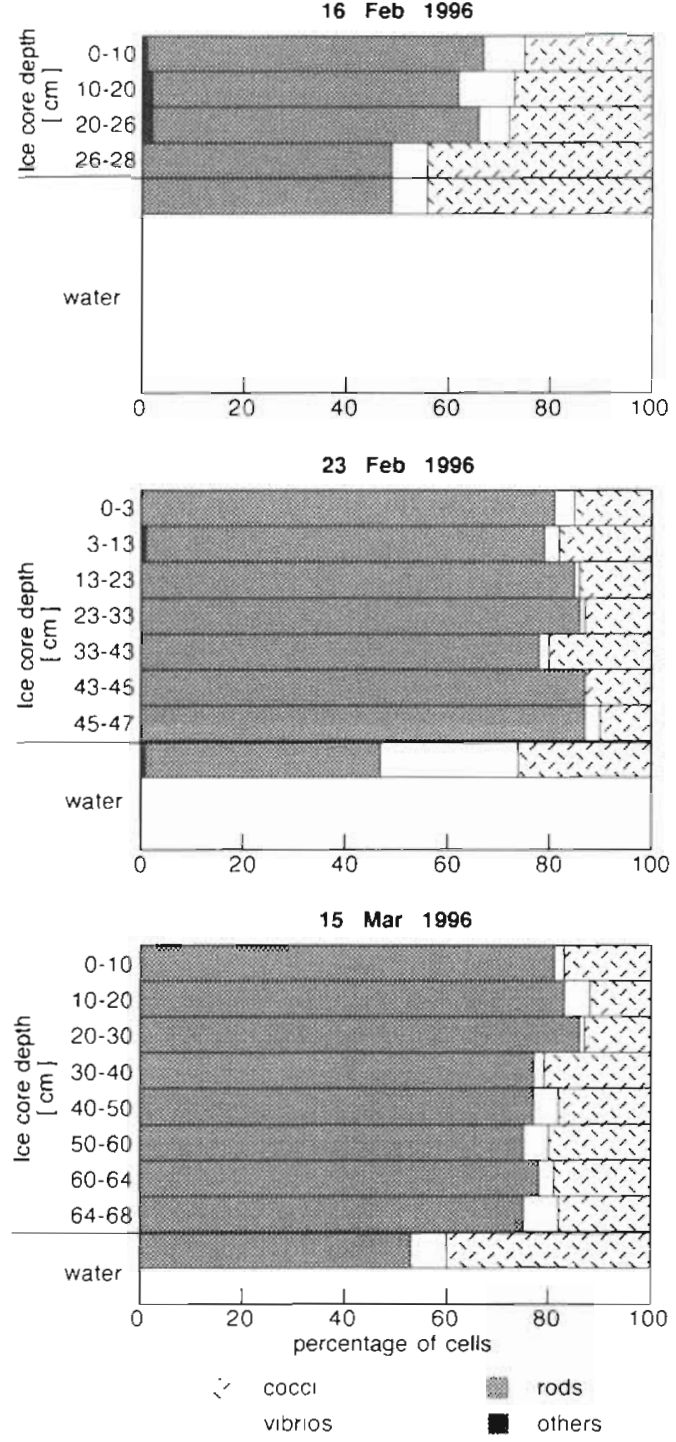

Fig. 11. Vertical distribution of bacterial morphotypes in sea ice and morphotypes for the under-ice bacterial assemblage

whereas low concentrations were characteristic for Arctic seawater (Table 2). Our nutrient concentrations of under-ice water were always higher than those of both polar regions but our brine and sea ice nutrient concentrations were within the range of polar sea ice (Table 2). Normalization of the data to open water salinities of polar areas would sharply increase the nutrient values. This step in data processing was omitted since salinities of 32 to 34 psu are unrealistically high for the investigated area. Interesting though, is the fact that, despite pronouced differences in salinities and consequently in concentration effects, nutrient levels within the ice were comparable to sea ice in high latitude areas. This may have been an important driving factor for the observed biological similarities discussed below.

Phytoplankton pigments of the Kiel Bight area from a long-term time series show maximum values of $5 \mu \mathrm{g}$ chl a $\mathrm{l}^{-1}$ within the euphotic zone in February where water temperatures are about $5^{\circ} \mathrm{C}$ (Hansen 1993). The over 4 -fold higher maximum chl a concentrations at $-0.3^{\circ} \mathrm{C}$ in the ice and the low phaeopigment:chl a ratios of the ice algae community imply that there were very favourable growth conditions in this habitat compared to phytoplankton chl a concentrations of ice free

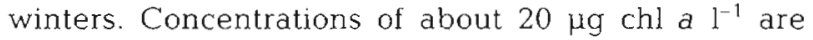
similar to phytoplankton spring bloom conditions which normally occur 1 mo later in March (Rheinheimer 1995). The early ice algae and the possibly early phytoplankton development in 1996 could be attributed to the high concentrations of nitrate, ammonium and silicate and to a reduction of water turbulence due to the ice cover. In addition sufficient availability of light can be assumed because snow cover was thin and the vertical extent of the ice sheet initially minimal

The maximum algal biomass in the ice on 16 Feb and 15 Mar was found in the bottom few centimetres (Fig 7). We always observed very porous bottom sections (Fig. 4) which contained a well-developed brine channel system. An enlarged brine volume may play a vital role for sea ice communities (Eicken 1992). An enrichment of algae in the bottom few centimetres can be explained by physical accumulation, by entrainment of brine, by superficial melt processes (Eicken 1992), or by growth. A chemical reason could be the availability of sufficiently high nutrient concentrations in the under-ice water (Maestrini et al. 1986). The relatively continuous increase of chl a from the top to the bottom of the ice core observed on 16 Feb and 15 Mar, although following the distribution of nutrients, is astonishing because 1 mo old ice, when found in the Antarctic, usually contains very heterogeneous distribution patterns of algae due to dynamic growth of the sea ice (Garrison et al. 1983, Shen \& Ackermann 1990). Despite the recorded variable environmental condi-

Fig. 12. Raster electron micrographs from samples of 23 February from the $0-3 \mathrm{~cm}$ section. (A) Dividing bacterium of the genus Caulobacter spp. (B) Other bacteria of the dimorphic prosthecate group. Micrographs from ice samples of $15 \mathrm{Mar}$ show $(C-E)$ short appendaged bacteria and $(F)$ bacteria with slime sheaths. Scale bar in $(B)$ and $(F)=2 \mu \mathrm{m}$, others $=1 \mu \mathrm{m}$ 

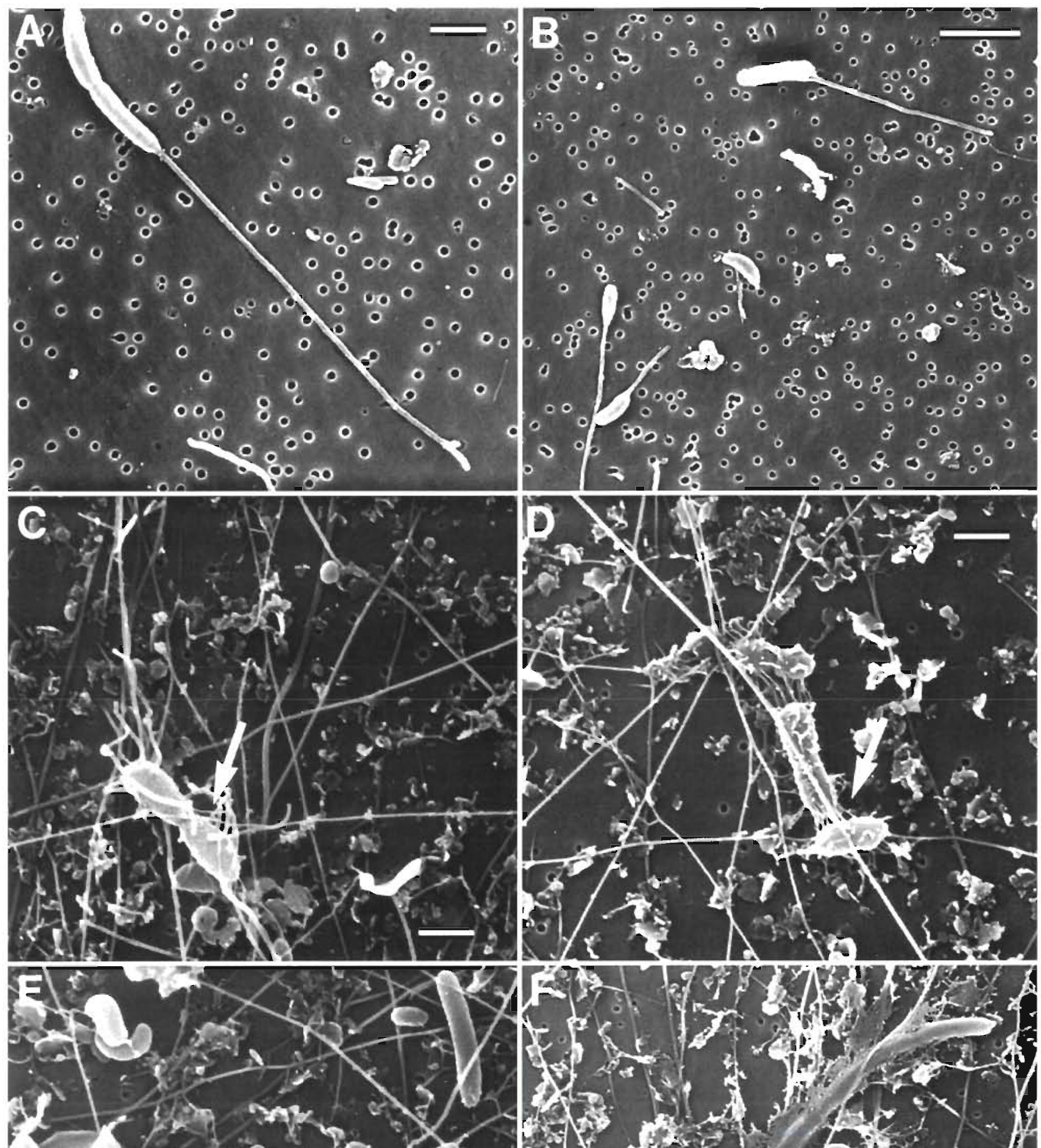

$x \rightarrow n^{2}$

1.

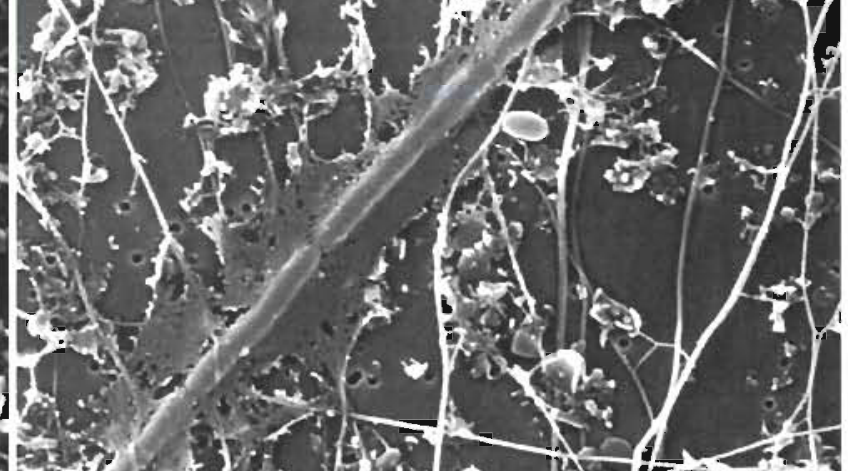

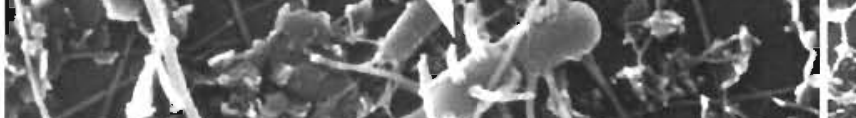

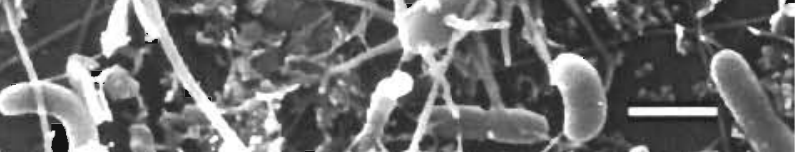

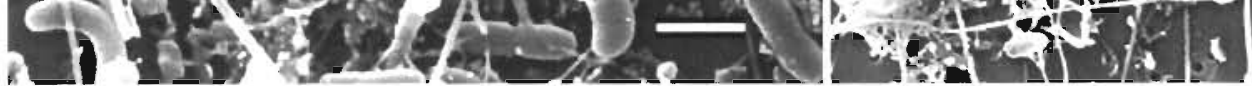
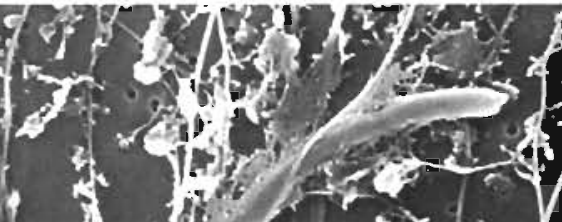

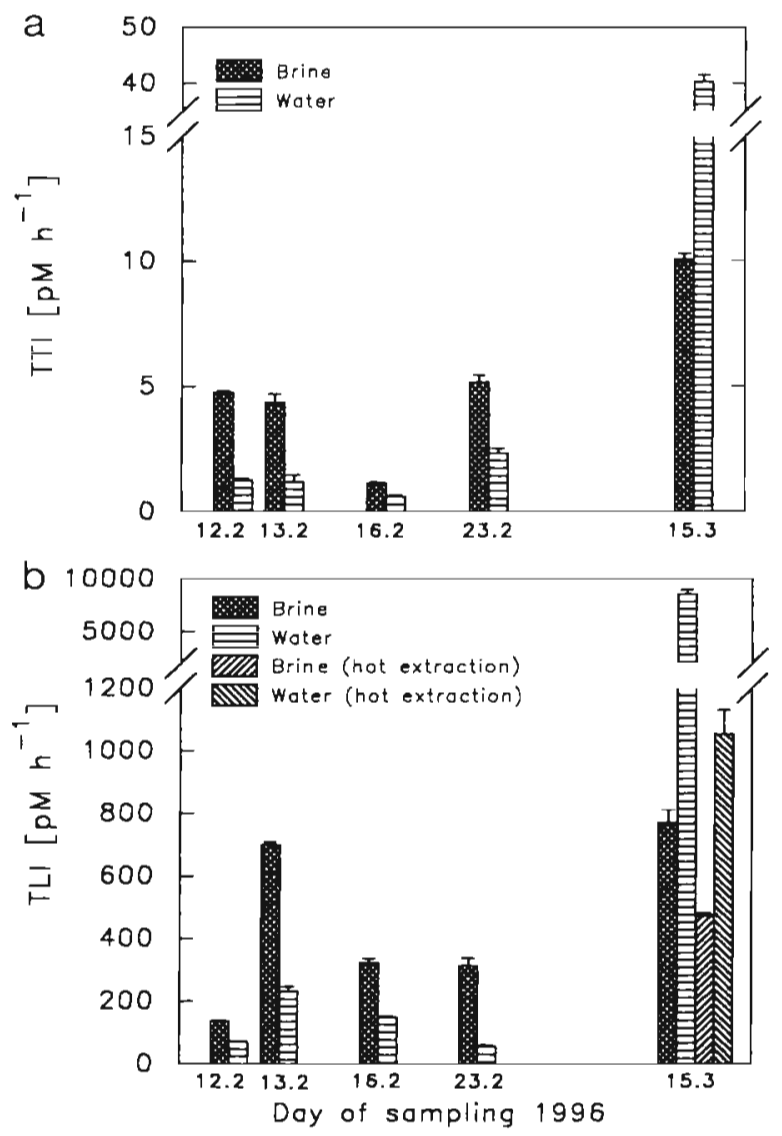

Fig. 13. Time course of (a) thymidine incorporation rates (TTI), and (b) leucine incorporation rates (TLI) in brine and underice water. Error bars denote standard deviations
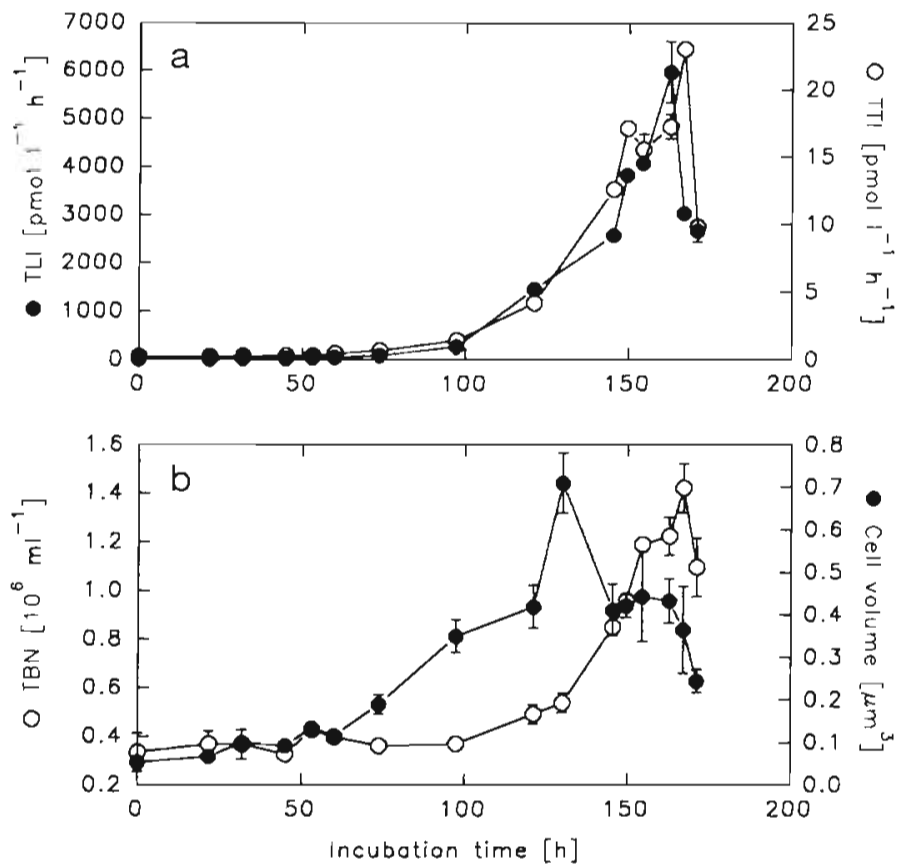

tions, the results indicate the development of a bottom ice community of ice algae (and bacteria) as proposed by Horner et al. (1988) for polar regions.

A totally inverse vertical distribution of chl a with maximum algal biomass in the top of the ice core was found on 23 Feb after a warmer west-wind event (Figs. $2 \& 7$ ). The west-wind period could have induced superficial melt processes after 16 Feb leading to an infiltration of seawater with an enrichment of microorganisms in the top layer (Garrison et al. 1983).

Initially (16 Feb) the ice community was dominated by algae and the biomasses of algae and bacteria were not significantly correlated (Fig. 15). After a time lag, bacterial cell division and growth resulted in a fair correlation between TBB and PIAC on 23 Feb. Within the thick, old ice (15 March) the slope of the regression between TBB and PIAC became flatter and highly significant $(p<0.005)$, but the $y$-intercept was higher. This implies 3 developmental stages of the microbial community within the sea ice of the Kiel Bight with the increasing importance of heterotrophic bacteria.

During the investigations daylength increased as did air temperatures due to more west-wind events after 13 Mar 1996. Irradiation towards the end of the study was also sufficient to enhance growth processes of phytoplankton under the ice. Unfortunately chl a was not measured in the under-ice water. However, chl a concentrations of $12 \mu \mathrm{g} \mathrm{l}^{-1}$ near the ice edge in open water were observed in early March (Horstmann, IfM Kiel, pers. comm.). A phytoplankton bloom in the underlying water could be responsible for the ob-

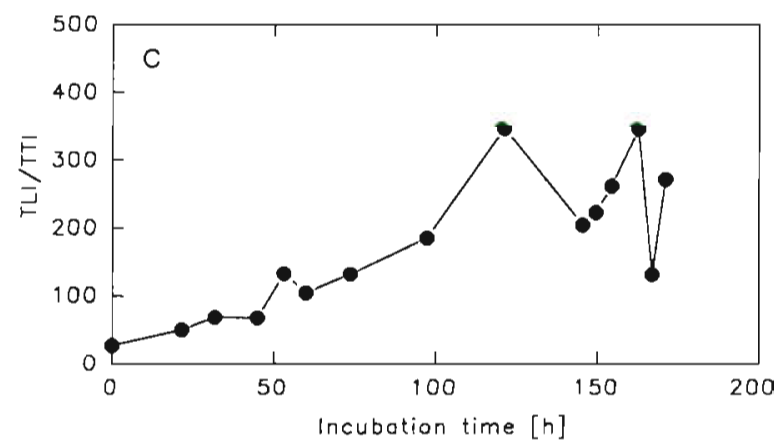

Fig. 14. Development of (a) thymidine (TTI) and leucine (TLI) incorporation rates, (b) total bacterial number (TBN) and average cell volume and (c) TLI:TTI ratios during the time course of the growth experiment with bacteria obtained from brine on 16 Feb 1996. Error bars denote standard deviations 


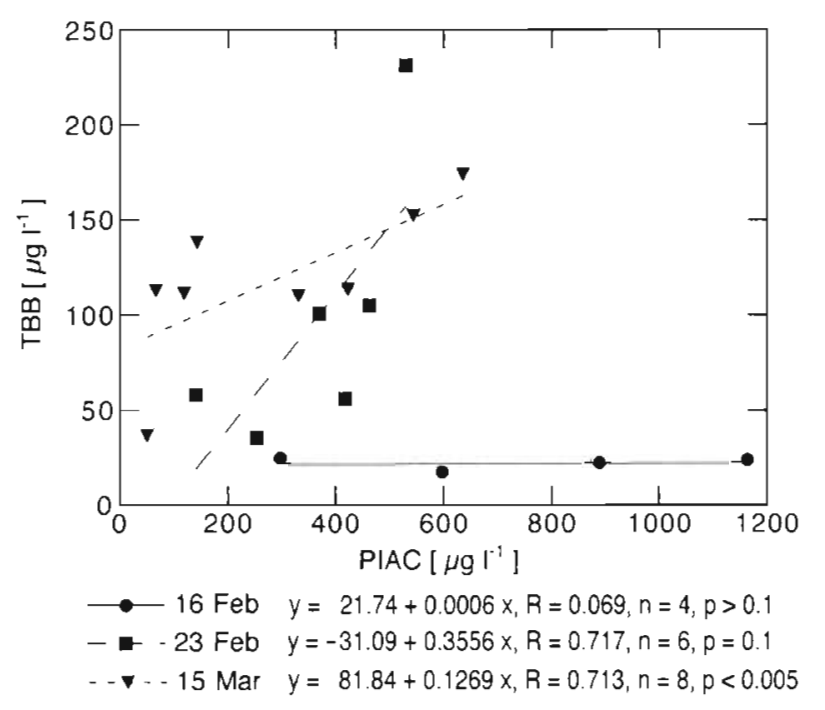

Fig. 15. Correlation between total bacterial biomass (TBB) and particulate ice algal carbon (PIAC) on the different. sampling occasions, with correlation coefficients from linear regression analysis. Error bars denote standard deviations

served drastic increase in bacterial abundance and secondary production in this habitat. The under-ice values of TBN and TBB exceeded those of more oligotrophic and deeper polar seas by far and were extremely high in comparison to normal winter water values (Table 3). Also TBB values in ice were conspicuously higher in comparision to water values of earlier years; meanwhile PIAC values were mostly within the range of particulate phytoplankton carbon (PPC) of earlier years (Fig. 16). Nevertheless, the biomass of both algae and bacteria within the ice remained high for the Kiel Bight, but with an emphasis on the heterotrophic component which had not before been observed to that extent in the Kiel Bight area. However, TBN, TBB and bacterial cell volume within Kiel Bight ice and brine was in the range of Arctic and Antarctic sea ice (Table 3).

The bacterial populations in ice and underlying water were distinctly different with respect to biovolume, size classes and morphotypes, the latter not showing any temporal change. One reason for the observed initial decrease of cell volume within the sea ice could be leakage of brine due to surface melt processes which removed bacterial cells and presumably organic material from the ice. The only small increase in bacterial cell volume in both habitats towards the end of the study indicates that the biomass production of the bacteria was dominated by an increase in cell number. At that timepoint an increase of individual volumes was obviously of minor importance, in contrast to the observation in the growth experiment of 16 Feb

Table 3. Comparison of microbiological data of polar regions and of the Baltic Sea in brine, ice and under-ice water; values are ranges or means. TBN: total bacterial number; TBB: total bacterial biomass; BSP: bacterial secondary production measured by thymidine incorporation

\begin{tabular}{|c|c|c|c|c|c|c|c|c|}
\hline & $\begin{array}{c}\text { TBN } \\
\left(10^{6} \text { cells } \mathrm{ml}^{-1}\right)\end{array}$ & $\begin{array}{c}\mathrm{TBB} \\
\left(\mu \mathrm{g} \mathrm{Cl}^{-1}\right)\end{array}$ & $\begin{array}{c}\text { Volume } \\
\left(\mu \mathrm{m}^{3}\right)\end{array}$ & $\begin{array}{c}\text { BSP } \\
\left(\mathrm{pmol} \mathrm{l}^{-1} \mathrm{~h}^{-1}\right)\end{array}$ & 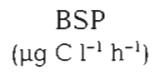 & Area & Season & Source \\
\hline \multirow[t]{3}{*}{ Brine } & $0.4-3.2$ & & & & & Antarctica & Late winter & Kivi \& Kuosa (1994) \\
\hline & $0.1-0.6$ & & & & & Antarctica, shelf & Whole year & Delille \& Rosier (1995) \\
\hline & $0.1-2.9$ & $5-98$ & $0.01-0.6$ & $0.25-5.2$ & $0.01-0.4$ & Antarctica & Fall & Grossmann \& Dieckmann (1994) \\
\hline \multirow[t]{2}{*}{ (Porewater) } & 2.21 & 11.5 & & $1.3-55.6$ & $0.08-3.82$ & Antarctica & Fall & Kottmeier \& Sullivan (1990) \\
\hline & $0.74-3.39$ & $10.2-60.9$ & $0.03-0.2$ & $1-10$ & $0.02-0.23$ & Kiel Fjord & Winter & This study \\
\hline \multirow{10}{*}{ (Grease) } & $0.3-27.66$ & & & & & Antarctica & Late winter & Kivi \& Kuosa (1994) \\
\hline & $0.18-1.14$ & $41-259$ & 0.65 & $0-3.6$ & $0-0.9$ & Arctic & Spring & Bunch \& Harland (1990) \\
\hline & 8.82 & 77.2 & 0.36 & & & Antarctica & Spring & Kottmeier \& Sullivan (1990) \\
\hline & & & 0.12 & $0.6-20.8$ & $0.01-0.6$ & Antarctica & Winter & Kottmeler \& Sullivan (1987) \\
\hline & 6.1 & 38.6 & 0.29 & 1.8 & 0.17 & Antarctica & Fall & Kottmeier \& Sullıvan (1990) \\
\hline & $0.004-18$ & 2 & $\leq 0.39$ & $0.9-5.1$ & $0.01-0.11$ & Antarctica & Winter & Helmke \& Weyland (1995) \\
\hline & $0.15-10$ & & & $0.5-3.5$ & & Arctic & Spring & Maranger et al. (1994) \\
\hline & 0.98 & 49.1 & 0.167 & $190_{\text {Leu }}$ & 0.57 & Antarctica, coast & Late summer & Grossmann (1994) \\
\hline & $0.1-1.5$ & & & & & Gulf of Bothnia & Winter & Norrman \& Andersson (1994) \\
\hline & $0.7-7$ & $15-270$ & $0.1-0.4$ & & & Kiel Fjord & Wunter & This study \\
\hline \multirow{6}{*}{$\begin{array}{l}\text { Under- } \\
\text { ice } \\
\text { water }\end{array}$} & & & & $0-1.9$ & $0-0.04$ & Antarctica & Winter & Kottmeier \& Sullivan (1990) \\
\hline & $0.05-0.5$ & & & & & Antarctica, shelf & Whole year & Delille \& Rosier (1995) \\
\hline & 0.27 & 10.4 & 0.11 & 0.36 & 0.015 & Arctic & Spring & (Bunch \& Harland (1990) \\
\hline & $0.04-0.2$ & 17.4 & $\leq 0.39$ & & & Antarctica & Winter & Helmke \& Weyland (1995) \\
\hline & 0.1 & 3 & 0.09 & $25_{\text {Leu }}$ & 0.01 & Antarctica, coast & Late summer & Grossmann (1994) \\
\hline & $0.57-5.51$ & $6.9-96.5$ & $0.03-0.13$ & $0.7-40$ & $0.01-0.91$ & Kiel Fjord & Winter & This study \\
\hline \multirow{3}{*}{$\begin{array}{l}\text { Winter } \\
\text { water }\end{array}$} & 0.87 & 11.64 & 0.039 & & 0.024 & Kiel Bight & Winter & Giesenhagen (1996a) \\
\hline & & $16-46$ & & & $0.01-0.02$ & Gulf of Finland & Winter & Heinänen (1992a) \\
\hline & 0.84 & & & 0.17 & 0.026 & Gulf of Bothnia & Winter & Heinänen (1992b) \\
\hline
\end{tabular}




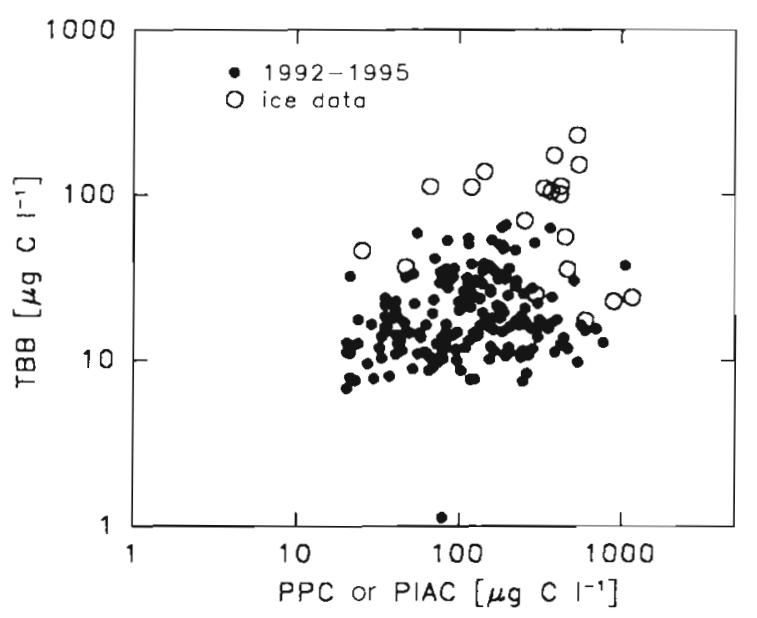

Fig. 16. Total bacterial biomass (TBB) versus phytoplankton carbon (PPC) values from the euphotic zone $(0$ to $20 \mathrm{~m})$ of Kiel Bight (1992-1995; taken from Giesenhagen 1996b) and $T B B$ versus particulate ice algae carbon ( $P[A C$ ) for the present ice data

The ice bacteria assemblage was dominated by rodshaped cells with a biovolume of 0.025-0.135 $\mu^{3}$ which were particularly evident in the bottom of the ice in a manner similar to the bottom surface of sea ice at Frobisher Bay in the Canadian subarctic (Bunch \& Harland 1990) and within ice of other polar regions (e.g. Helmke \& Weyland 1995). The bacterial assemblage in the underlying water was also dominated by rod-shaped cells but smaller cocci also contributed a large part of the total bacterial biomass. The largest bacteria in the ice $\left(0.135-0.9 \mu \mathrm{m}^{3}\right)$ consisted of large rods which frequently occupied the top of the ice. The virtual absence of these bacteria in water (Figs. 10 \& 11) provides evidence of an ice-specific group of bacteria or at least ice-specific factors controlling this shift in size classes.

The variety of distinct morphological bacterial types within the ice, including bacteria with slime sheaths and with appendages, is very common (about 20\%) among sea ice isolates from the Antarctic (Helmke \& Weyland 1995). Similar morphotypes were also found within the sea ice of the Kiel Bight (Fig. 12) and amounted to $11 \%$ of the total on 23 Feb. Hyphenating bacteria were virtually absent on 15 Mar and otherwise appendaged bacteria could not be distinguished by epfluorescence microscopy. Investigations by scanning electron microscopy were performed only qualitatively and not quantitatively. Therefore, the absolute percentage of these types of bacteria cannot be provided and the number given is a conservative estimate. However, the results indicate a similar shift in morphotypes for brackish water ice as is found in the ice of polar areas.

Average cell volumes of about $0.3 \mathrm{\mu m}^{3}$ for ice bacteria of various sea ice habitats have frequently been observed by Kottmeier \& Sullivan (1990) Enlarged cell volumes of Arctic bacteria have been attributed to both low temperature and high nutrient concentration (Wiebe et al. 1992). Large cells can also be the result of low grazing pressure within the ice (Turley et al. 1986). During the temporal development of the brackish ice bacterial community a shift in size classes occurred. The smallest bacteria decreased over time indicating growth due to high substrate concentrations and insignificant control by grazing

The supposed low influence of grazers on the overall development of the standing stock of bacteria should be discernible in a correlation between bacterial production (based on TTI) and TBN. The temporal development of bacterial production closely followed that of TBN (Fig. 17). Bunch \& Harland (1990) found an increase of cell production from 0 to $7.6 \times 10^{6}$ cells $1^{-1}$ $\mathrm{h}^{-1}$ between March and May 1986 in first-year ice at Frobisher Bay (Canadian Subarctic) but only a 5-fold increase in the standing stock of bacteria, which supported the hypothesis of predation and/or export of the standing stock of cells to the water column. Because of the good agreement between bacterial production and TBN in our study (e.g. both doubled within the ice)
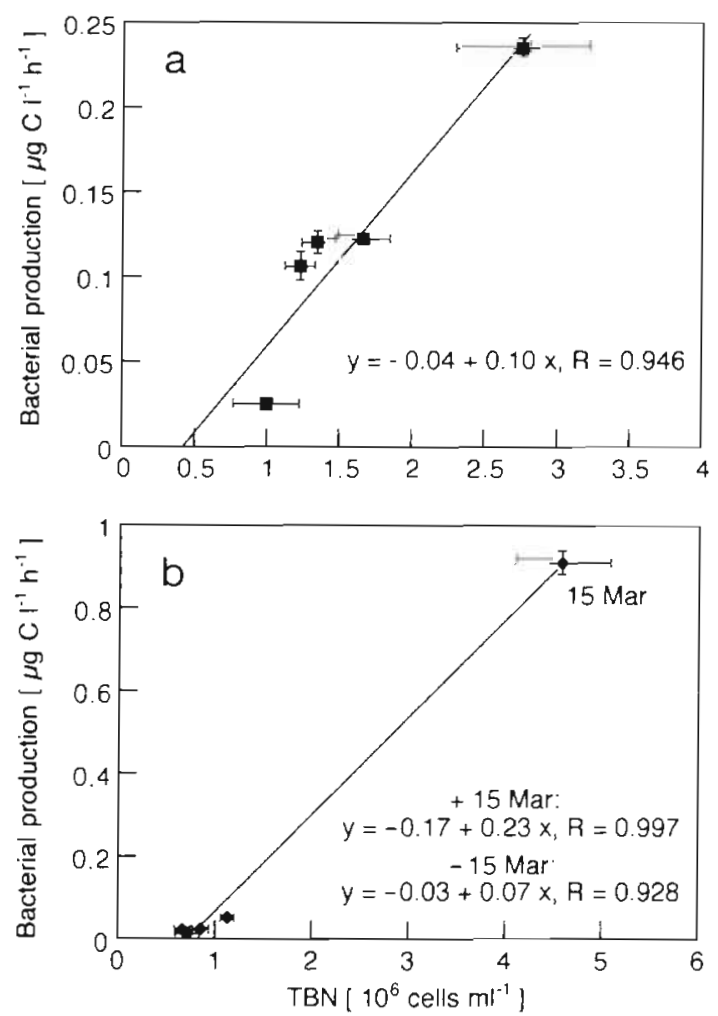

Fig. 17. Correlations between bacterial production measured by thymidine incorporation rates and total bacterial number (TBN) in (a) brine and (b) under-ice water. The regressions for under-ice water are given for all dates (+ $15 \mathrm{Mar}$ ) and without the last sampling date (-15 Mar) 
significant predation and/or export of bacterial cells within sea ice and underlying water during the icecovered period in the Kiel Bight can be excluded (cf. Billen et al. 1990). A comparison between potential biomass data, calculated from generation times, and actual standing stocks is likewise difficult due to the pronounced hydrographic changes and coupled water exchange processes which affected the investigation. However, the increase in TBB by a factor of 3 to 4 between the last 2 sampling dates ( $20 \mathrm{~d}$ ) fits to an average generation time of 6 to $7 \mathrm{~d}$ in ice and underlying water during that period and indicates no loss due to grazing. This indirect proof of the absence of consumers belonging to the nanoplankon size fraction is supported by the virtual absence of the micro- and mesozooplankton during the ice-covered period until the begining of summer (Behrends, IfM Kiel, pers. comm.) Nonetheless, the total bacterial biomass (as well as the biomass of ice algae) that was not ingested during the ice-covered period may be released during ice melting and then contribute to a carbon outflow from the sympagic system.

One of the most interesting findings during the ice investigation was the occurrence of extremely high leucine incorporation rates in relation to the measured thymidine uptake. There are no reports about TLI:TTI ratios as high as those reported here either for the Baltic or for sea ice or open water in polar areas. There are 2 possible explanations for this: (1) In the icerelated literature, data obtained by the hot-extraction procedure are presented (e.g. Grossmann \& Dieckmann 1994) and deviations between the 2 extraction procedures are therefore unknown, and (2) the literature concerning production estimates from leucine in polar open water areas and the Baltic includes mainly data measured by the cold-extraction procedure (e.g. Tupas et al. 1994, Giesenhagen 1996a, Lochte et al. 1997) and does not show high TLI: TTI ratios similar to the open water experiment (data not presented).

Our results indicate that within and beneath the sea ice, unspecific labeling by leucine was high and characteristic for the ice situation. A non-protein macromolecule which remains in the cold TCA-insoluble fraction is leucyl-tRNA. During a period of increasing growth rate (see below), assimilation of leucine into leucyl-tRNA may be faster than its incorporation into proteins (Chin-Leo \& Kirchman 1988). High coldextraction values can also result from the synthesis and degradation of proteins, i.e. protein turnover, independent of net growth (Kirchman et al. 1985). Tupas et al. (1994) discussed high uptake rates of amino acids in Antarctic coastal waters which are mineralized to a large degree to ammonia. Although high uptake rates of amino acids should not affect the production estimate since they are only cycled within the cell rather than being incorporated, they still may influence the measurement. However, it is unclear why the uptake of leucine should be much higher than required for biosynthesis. In spite of favourable growth conditions during the ice-covered period, a lack of certain substantial substrates inducing a high quasi-compensatory flux of amino acids into the cell could serve as a possible explanation.

TLI values obtained by the hot-extraction procedure on 15 Mar resulted in still higher TLI:TTI ratios of 25-40:1 compared to common ratios of 5-10:1 within water and sea ice (Chin-Leo \& Kirchman 1988, Grossmann \& Dieckmann 1994J. Higher ratios can be explained by a large proportion of active but nondividing cells (Tabor \& Neihoff 1984, Kirchman et al. 1985, Grossmann 1994). The increase in bacterial mean cell volume during the growth experiment indicated that an appreciable fraction of the bacterial production originated from cell enlargement and not from cell division alone. Furthermore, enlarged cells incorporate relatively more leucine than smaller cells (Servais 1992). Also, uncoupling between the synthesis rates of protein and DNA under selected growth conditions such as shifts from low to high growth rates can result in elevated ratios (Ingraham et al. 1983, ChinLeo \& Kirchman 1990). Dissolved free amino acids and ammonia can stimulate the average growth rate (Kirchman 1990). A comparable stimulation can be assumed during our study because of high ammonia concentrations up to $34 \mu \mathrm{M}$. However, this cannot be easily proven by the production/biomass ratios due to the previously mentioned water exchange processes. It is only indicated for the last sampling day in the underice water when generation times dropped to $2.7 \mathrm{~d}$.

Uptake of leucine by algae is discussed by Bjørnsen \& Kuparinen (1991) to raise the incorporation rates when added concentrations are high. This may be of importance when saturation levels are in the range of 10 to $20 \mathrm{nM}$. For Baltic Sea samples saturation concentrations need to be much higher and sometimes saturation levels are unattainable (Heinänen, Finnish Institute of Marine Research, Helsinki, pers. comm.). The effect of addition of $100 \mathrm{nM}$ leucine was checked in a saturation level experiment for brine and underice water (data not shown), and was eliminated as a factor that may have stimulated uptake by algae

Since the production estimates based on the measurement of leucine incorporation rates were obviously affected by unspecific labelling and unfortunately not always checked, a comparison of bacterial production in brackish water ice compared to polar regions and to winter values encountered in the Baltic Sea was restricted to the thymidine method (Table 3 ). Bacterial production within brine from the Kiel Bight was similar to that reported from the Arctic and Antartic, espe- 
cially when data from young ice (2 to 3 mo) are compared (Kottmeier \& Sullivan 1990, Grossmann \& Dieckmann 1994). On the other hand, the under-ice water maximum production was much higher, in relation to both the Kiel Bight winter values and to underice values from polar areas. The ice situation rapidly changed the nutrient regime in our area and is not comparable to that of polar regions. The bacteria were likely among the first to benefit from the nutrient and substrate supply via e.g. phytoplankton exudation and to respond with comparably high activity (leucine incorporation) and production rates.

Summarizing the results of the ice investigation, the ice situation in winter 1995/96 supported the growth and development of the bacterial community in the Kiel Bight area. The bacterial biomass over this winter exceeded biomass from former years by far because of sufficient nutrient and substrate supply and low grazing pressure during the ice-covered period. A comparison with Arctic and Antarctic sites revealed that TBN, TBB, bacterial biovolume, morphotypes and bacterial production within sea ice of the Kiel Bight showed many similarities to those found in sea ice of polar regions. This finding was not expected because the development of a solid ice cover at this latitude in the Baltic Sea is rare. The adaptation of different bacterial groups to the new environment of sea ice and concurring physical processes apparently always takes place in a comparable way, which could explain this similarity. It is also most likely that cold-adapted bacterial groups exist in the southern regions of the Baltic Sea and to a certain extent are responsible for a corresponding development. While psychrotrophic bacteria can be assumed to be present in the water this may not be true for strictly psychrophilic bacteria which are thought to be essentially restricted to polar areas and to make sea ice microbial assemblages exclusive for these regions (e.g. Delille 1992). We did not perform any physiological tests to check whether or not the observed similarities could be attributed to the existence of psychrophilic bacteria. However, Helmke \& Weyland (1991) demonstrated the existence of psychrophilic bactena in North Sea sediments during winter although their tests failed in summer. Although there is no hint as to how this group survives warm periods, it obviously does. Since psycrophilic bacteria are part of the winter populations in the North Sea, there is no reason to absolutely exclude their possible appearance in the adjacent Baltic Sea. It will be most interesting if future studies conducted on brackish water ice in temperate regions are able to prove whether the observed similarities are restricted to functional aspects of the symphagic systems or whether there are also clear accordances with regard to their structure beyond those observed by scanning electron microcopy.
Acknowledgements. We thank M. Bittner, R. Gradinger, $H$. Johannsen, T Jung, R. Koppe, C. Krembs and P. Lehre for their help during the investigation and we are grateful to $R$. Schmaljohann for preparing the scanning electron micrographs. This project was funded by the Bundesministerium für Bildung und Wissenschaft, Forschung und Technologie (BMBF), project number 03F0166A.

\section{LITERATURE: CITED}

Ackley SF, Sullivan CW (1994) Physical control on the development and characteristics of Antarctic sea ice biological communities - a review and synthesis. Deep Sea Res 41: $1583-1604$

Andersson A, Rudehäll A (1993) Proportion of plankton biomass in particulate organic carbon in the northern Baltic Sea. Mar Ecol Prog Ser 95:133-139

Arar EJ, Collins GB (1992) In vitro determination of chlorophyll $a$ and phaeophytin $a$ in marine and freshwater phytoplankton by fluorescence. Method 445.0. In: USEPA, Methods for the determination of chemical substances in marine and estuarine environmental samples. EPA, Cincinnati, $\mathrm{OH}$

Balzer W, Meyer-Reil LA, Faubel A, Graf G, Pollehne F (1987) Diagenesis and exchange processes at the benthic boundary. In: Ruhmor $J$, Walger E, Zeitzschel B (eds) Seawatersediment interactions in coastal waters. Lecture Notes on Coastal and Estuarine Studies 13. Springer Verlag, Berlin, p $111-161$

Billen G, Servais P, Becquevort S (1990) Dynamics of bacterioplankton in oligotrophic and eutrophic aquatic environments: bottom up or top down control? Hydrobiologia 207:37-42

Bjørnsen PK, Kuparinen J (1991) Determination of bacterioplankton biomass, net production and growth efficiency in the Southern Ocean. Mar Ecol Prog Ser 71:185-194

Bunch JN, Harland RC (1990) Bacterial production in the bottom surface of sea ice in the Canadian Subarctic. Can J Fish Aquat Sci 47:1986-1995

Chin-Leo G, Kirchman DL (1988) Estimating bacterial production in marine waters from the simultaneous incorporation of thymidine and leucine. Appl Environ Microbiol 54.(8): $1934-1939$

Chin-Leo G, Kirchman DL (1990) Unbalanced growth in natural assemblages of marine bacterioplankton. Mar Ecol Prog Ser 63:1-8

Cota GF, Prinsenberg SJ, Bennett EB, Loder JW, Lewis MR, Anning JL, Watson NHF (1987) Nutrient fluxes during extended blooms of Arctic ice algae. I Geophys Res 92(C2):1951-1962

Cox GFN, Weeks WF (1983) Equations for determining the gas and brine volumes in sea-ice samples. J Glaciol 29 . $306-316$

Delille D (1992) Marine bacterioplankton at the Weddell Sea ice edge, distribution of psychrophilic and psychrotrophic populations. Polar Biol 12:205-210

Delille D, Rosier C (1995) Seasonal changes of Antarctic marine bacterioplankton and sea ice bacterial assemblages. Polar Biol 16:27-34

Dieckmann GS, Lange MA, Ackley SF, Jennings JC (1991) The nutrient status in sea ice of the Weddell Sea during winter: effects of sea ice texture and algae. Polar Biol 11 $449-456$

Eicken $H$ (1992) The role of sea ice in structuring Antarctic ecosystems. Polar Biol 12:3-13

Fuhrman JA, Azam F (1982) Thymidine incorporation as a 
measure of heterotrophic bacterioplankton production in marine surface waters: evaluation and field results. Mar Biol 66:109-120

Frankenstein G, Garner R (1967) Equations for determining the brine volume of sea ice from $-0.5^{\circ} \mathrm{C}$ to $-22.9^{\circ} \mathrm{C}$. J Glaciol 6:943-944

Garrison DL, Ackley SF, Buck KR (1983) A physical mechanism for establishing algal populations in frazil ice. Nature 306:363-365

Garrison DL, Buck KR (1986) Organism losses during ice melting: a serious bias in sea ice community studies. Polar Biol 6:237-239

Garrison DL, Close AL, Reimnitz E (1989) Microorganisms concentrated by frazil ice: evidence from laboratory and field measurements. Antarct Sci 1:313-316

Giesenhagen HC (1996a) Bakterielle Aktivität im Pelagial der Kieler Bucht (Westliche Ostsee). Ein Vergleich zwischen Deckschicht und bodennahem Wasser Dissertation, Univ Kiel

Giesenhagen HC (1996b) Mikrobiologie. In: Final report of the BMBF projekt 03F0547A. Erarbeitung der wissenschaftlichen Grundlagen sowie Beschaffung und Bewertung der Daten für das Biologische Monitoring der Ostsee 1985-1995. Institut für Meereskunde, Kiel, p 80-103

Gleitz M, Vonderloeff MR, Thomas DN, Dieckmann GS Millero FJ (1995) Comparison of summer and winter inorganic carbon, oxygen and nutrient concentrations in Antarctic sea ice brine. Mar Chem 51(2):81-91

Grasshoff K, Ehrhardt M, Kremling K (1983) Methods of seawater analyses, 2nd edn. Verlag Chemie, Weinheim

Grossmann S (1994) Bacterial activity in sea ice and open water of the Weddell Sea, Antarctica: a microautoradiographic study. Microb Ecol 28:1-18

Grossmann S, Dieckmann GS (1994) Bacterial standing stock, activity, and carbon production during formation and growth of sea ice in the Weddell Sea, Antarctica. Appl Environ Microbiol 60:2746-2753

Hansen HP (1993) Saisonale und langzeitliche Veränderungen chemisch-hydrographischer Parameter in der Kieler Bucht. In: Duinker JC (ed) Das biologische Monitoring der Ostsee im Institut für Meereskunde Kiel 1985-1992. Ber Inst Meereskde Kiel 240:2-31

Heinänen A (1992a) Bacterioplankton in the open Baltic. Finn Mar Res 260

Heinänen A (1992b) Bacterioplankton in a subarctic estuary: the Gulf of Bothnia (Baltic Sea). Mar Ecol Prog Ser 86: $123-131$

Helmke E, Weyland H (1991) Effect of temperature on extracellular enzymes occurring in permanently cold marine environments. In: Rheinheimer G, Gocke K, Hoppe HG, Lochte K, Meyer-Reil LA (eds) Distribution and activity of microorganisms in the Sea. Kieler Meeresforsch Sonderh 8:198-204

Helmke E, Weyland $H$ (1995) Bacteria in sea ice and underlying water of the eastern Weddell Sea in midwinter. Mar Ecol Prog Ser 117:269-287

Horner RA, Syvertsen EE, Thomas DP, Lange C (1988) Proposed terminology and reporting units for sea ice algal assemblages. Polar Biol 8:249-253

Hudier E, Ingram G (1994) Small scale melt processes governing the flushing of nutrients from a first-year sea ice, Hudson Bay, Canada. Oceanol Acta 17:397-403

Ingraham JL, Maaløe O, Neidhardt FC (1983) Growth of the bacterial cell. Sinauer Assoc Inc, Sunderland, MA

Kirchman DL (1990) Limitation of bacterial growth by dissolved organic matter in the subarctic Pacific. Mar Ecol Prog Ser 62:47-54
Kirchman DL, Ducklow HW (1993) Estimating factors conversion factors for the thymidine and leucine methods for measuring bacterial production. In: Kemp PF, Sherr BF, Sherr EB, Cole JJ (eds) Handbook of methods in aquatic microbial ecology. Lewis Publ, London, p 513-518

Kirchman DL, K'nees E, Hodson RE (1985) Leucine incorporation and its potential as a measure of protein synthesis by bacteria in natural aquatic ecosystems. Appl Environ Microbiol 49:599-607

Kivi K, Kuosa H (1994) Late winter microbial communities in the western Weddell Sea (Antarctica). Polar Biol 14 389-399

Kottmeier ST, Sullivan CW (1987) Late winter primary production and bacterial production in sea ice and seawater west of the Antarctic Peninsula. Mar Ecol Prog Ser 36 : $287-298$

Kottmeier ST, Sullivan CW (1990) Bacterial biomass and production in pack ice of Antarctic marginal ice edge zones. Deep Sea Res 37:1311-1330

Legendre L, Martineau MJ, Therriault JC, Demers S (1992) Chlorophyll a biomass and growth of sea-ice microalgae along a salinity gradient (southeastern Hudson Bay, Canadian Arctic). Polar Biol 12:445-453

Leppäranta M, Manninen T (1988) The brine and gas content of sea ice with attention to low salinities and high temperatures. Finn Inst Mar Res Internal Rep 2:1-14

Lochte K, Bjørnsen PK, Giesenhagen HC, Weber A (1997) Bacterial standing stock and production and their relation to phytoplankton in the southern ocean. In: Smetacek $V$, de Baar HJW, Bathmann UV, Lochte K, Rutgers van der Loeff MM (guest eds) Ecology and biogeochemistry of the Antarctic circumpolar current during austral spring: Southern Ocean JGOFS cruise ANT X/6 of RV Polarstern. Deep Sea Res 44(1-2) 321-340

Maestrini SY, Rochet M. Legendre L, Demers S (1986) Nutrient limitation of the bottom-ice microalgae biomass (southern Hudson Bay, Canadian Arctic). Limnol Oceanogr 31(5):969-982

Maranger R, Bird DF, Juniper SK (1994) Viral and bacterial dynamics in Arctic sea ice during the spring algal bloom near Resolute, N.W.T., Canada. Mar Ecol Prog Ser 111: $121-127$

Norman B, Andersson A (1994) Development of ice biota in a temperate sea area (Gulf of Bothnia). Polar Biol 14: $531-537$

Palmisano AC, Garrison DL (1993) Microorganisms in Antarctic sea ice. In Friedmann El (eds) Antarctic microbiology. Wiley, New York, p $167-218$

Rheinheimer G (1995) Meereskunde der Ostsee, 2nd edn. Springer Verlag, Berlin

Servais P (1992) Bacterial production measured by $\left[{ }^{3} \mathrm{H}\right]$ thymidine and $\left[{ }^{3} \mathrm{H}\right.$ lleucine incorporation in various aquatic ecosystems. Arch Hydrobiol 37:73-81

Shen HT, Ackermann NL (1990) Wave-induced sediment enrichment in coastal ice covers. In: Ackley SF, Weeks WF (eds) Sea ice properties and processes. Hannover CRREL Monogr 90-1, p 100-102

Simon M. Azam F (1989) Protein content and protein synthesis rates of planktonic Marine bacteria. Mar Ecol Prog Ser 51:201-213

Smetacek $V$, Bodungen BV, Bröckel KV, Knoppers $B$, Martens P, Peinert R, Pollehne F, Stegmann P, Zeitzschel B (1987) Seasonality of plankton growth and sedimentation. In: Ruhmor J, Walger E, Zeitzschel B (eds) Seawatersediment interactions in coastal waters. Lecture Notes on Coastal and Estuarine Studies 13. Springer Verlag, Berlin, p 34-56 
Smith REH, Harrison WG Harris LR, Herman AW (1990) Vertical fine structure of particulate matter and nutnents in sea ice of the high Arctic. Can J Fish Aquat Sci 47. $1348-1355$

Spindler M, Dieckmann GS (1986) Distribution and abundance of the planktic foraminifer Neogloboquadrina pachyderma in sea ice of the Weddell Sea (Antarctica). Polar Biol 5:185-191

Strübing K (1995) Eisverhältnisse. In: Reinheimer G (ed) Meereskunde der Ostsee, 2nd edn. Springer Verlag, Berlin

Tabor PS, Neihof RA (1984) Direct determination of activities for microorganisms of Chesapeake Bay populations. Appl Environ Microbiol 48:1012-1019

Editorial responsibility: Otto Kinne (Editor), Oldendorf/Luhe, Germany
Tupas LM, Koike l, Karl DM, Holm-Hansen O (1994) Nitrogen metabolism by heterotrophic bacterial assemblages in Antartic coastal waters. Polar Biol 14:195-204

Turley CM. Hughes DJ (1992) Effects of storage on direct estimates of bactenal numbers preserved seawater samples Deep Sea Res 39:375-394

Turley CM, Newell RC, Robins DB (1986) Survival strategies of two small Marine ciliates and their role in regulating bacterial community structure under experimental conditions. Mar Ecol Prog Ser 33:59-70

Wiebe WJ, Sheldon WM Jr, Pomeroy LR (1992) Bacterial growth in the cold: evidence for enhanced substrate requirement. Appl Environ Microbiol 58:359-364

Submitted: December 19, 1996; Accepted: August 22, 1997 Proofs received from author(s): October 20,1997 